\title{
Valorization of Brewery Wastes for the Synthesis of Silver Nanocomposites Containing Orthophosphate
}

\author{
Alcina Johnson Sudagar ${ }^{1, *,+} \mathbb{D}$, Neha Venkatesh Rangam ${ }^{1, *}+\mathbb{D}^{\mathbb{D}}$, Artur Ruszczak ${ }^{1} \mathbb{D}$, Paweł Borowicz ${ }^{1}$,

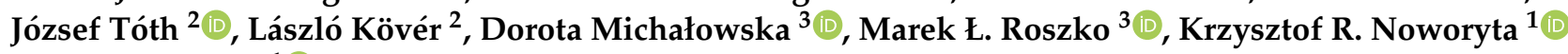 \\ and Beata Lesiak ${ }^{1}$ (D)
}

check for

updates

Citation: Sudagar, A.J.; Rangam, N.V.; Ruszczak, A.; Borowicz, P.; Tóth, J.; Kövér, L.; Michałowska, D.; Roszko, M.Ł.; Noworyta, K.R.; Lesiak, B. Valorization of Brewery Wastes for the Synthesis of Silver Nanocomposites Containing Orthophosphate. Nanomaterials 2021, 11, 2659. https://doi.org/10.3390/ nano11102659

Academic Editor: Ana María Díez-Pascual

Received: 5 September 2021 Accepted: 4 October 2021 Published: 10 October 2021

Publisher's Note: MDPI stays neutral with regard to jurisdictional claims in published maps and institutional affiliations.

\section{Copyright: (c) 2021 by the authors.} Licensee MDPI, Basel, Switzerland. This article is an open access article distributed under the terms and conditions of the Creative Commons Attribution (CC BY) license (https:// creativecommons.org/licenses/by/ $4.0 /)$.
1 Institute of Physical Chemistry, Polish Academy of Sciences, Kasprzaka 44/52, 01-224 Warsaw, Poland; aruszczak@ichf.edu.pl (A.R.); pborowicz@ichf.edu.pl (P.B.); knoworyta@ichf.edu.pl (K.R.N.); blesiak-orlowska@ichf.edu.pl (B.L.)

2 Institute for Nuclear Research, BemTér 18/c, H-4026 Debrecen, Hungary; toth.jozsef@atomki.hu (J.T.); kover.laszlo@atomki.hu (L.K.)

3 Institute of Agriculture and Food Biotechnology-State Research Institute, ul. Rakowiecka 36, 02-532 Warsaw, Poland; dorota.michalowska@ibprs.pl (D.M.); marek.roszko@ibprs.pl (M.Ł.R.)

* Correspondence: sudagaralcinajohnson@gmail.com or asudagar@ichf.edu.pl (A.J.S.); nehavr25@gmail.com (N.V.R.)

$\dagger$ These authors contributed equally to this work.

\begin{abstract}
Brewery wastes from stage 5 (Wort precipitate: BW5) and stage 7 (Brewer's spent yeast: BW7) were valorized for the synthesis of silver phosphate nanocomposites. Nanoparticles were synthesized by converting silver salt in the presence of brewery wastes at different temperatures (25, 50 , and $80^{\circ} \mathrm{C}$ ) and times (10,30, and $\left.120 \mathrm{~min}\right)$. Unexpectedly, BW7 yielded $\mathrm{Ag}_{3} \mathrm{PO}_{4}$ nanoparticles with minor contents of $\mathrm{AgCl}$ and $\mathrm{Ag}$ metal ( $\mathrm{Ag}_{\text {met }}$ ). Contrastingly, BW5 produced $\mathrm{AgCl}$ nanoparticles with minor amounts of $\mathrm{Ag}_{3} \mathrm{PO}_{4}$ and $\mathrm{Ag}$ met. Nanocomposites with different component ratios were obtained by simply varying the synthesis temperature and time. The morphology of the nanocomposites contained ball-like structures representative of $\mathrm{Ag}_{3} \mathrm{PO}_{4}$ and stacked layers and fused particles representing $\mathrm{AgCl}$ and $\mathrm{Ag}_{\text {met }}$. The capping on the nanoparticles contained organic groups from the brewery by-products, and the surface overlayer had a rich chemical composition. The organic overlayers on BW7 nanocomposites were thinner than those on BW5 nanocomposites. Notably, the nanocomposites exhibited high antibacterial activity against Escherichia coli ATCC 25922. The antibacterial activity was higher for BW7 nanocomposites due to a larger silver phosphate content in the composition and a thin organic overlayer. The growth of $\mathrm{Ag}_{\mathrm{met}}$ in the structure adversely affected the antimicrobial property of the nanocomposites.
\end{abstract}

Keywords: green chemistry; nanoparticles; waste valorization; antibacterial; silver phosphate

\section{Introduction}

Globally, the brewing industry is a significant source of waste effluents. Management of this waste is increasingly a problem due to the increased annual production rate [1] Brewery industry wastes have not been widely explored as materials for synthesis and particularly not in terms of nanoparticle synthesis. However, brewery waste analysis has been performed to determine its constituents. Amino acids, phosphates, polyphenols, proteins, and sugars have been determined and quantified [2]. Brewery waste remediation and valorization research have shown potential in different application fields. Brewery waste has been used as the carbon source for the Bacillus Subtilis N3-1P bacterium to synthesize biosurfactants [3]. Fractionation and purification of brewery waste have been performed to obtain bioactive compounds in food, pharmaceutical, agricultural, cosmetic, and chemical industries [4,5]. Nevertheless, there is still much scope in the field of brewery wastes valorization. 
The production of malt beer occurs in a 10-step process that leads to brewery waste at various production stages (Scheme 1) [6]. Malt is a sprouted and dried cereal grain, in this case, barley. Malting comes down to steeping the cleaned grain and maintaining its moisture for a sufficiently long time. Steeping, which lasts from three to four days, aims to wake the embryos from sleep and initiate germination. This process is accompanied by the secretion of enzymes in the grain that break down excess protein and sugars. Amylase helps break down barley starch into simple sugars and disaccharides (primarily maltose). It is vital to break down as many spare materials into simple sugars and amino acids in malting. The malt is then milled, mixed with water, and mashed to dissolve the starch and protein, releasing sugar and tannin. The sweet malt extract called wort is separated from the solid substances at the third stage called Brewer's spent grains (BSG) and is the first type of waste, BW3. In the following stage, the wort is boiled after adding the bitter, aromatic hops and sometimes sugar. The tannin and part of proteins are separated during boiling. The wort is clarified in a whirlpool and the clear wort is tapped out. The undissolved hop particles and proteins are collected at the whirlpool center, forming the second type of waste (BW5) called wort precipitate. The clear wort is then cooled and fermented by adding yeast. Absorbed nutrients not used by the embryo are the substrate of the alcoholic fermentation carried out by yeast in the brewery while brewing beer. The yeast filtered out after fermentation called Brewer's spent yeast (BSY) at the seventh stage forms the third type of waste, BW7. After maturing, the fermented beer is filtered using diatomaceous earth before going into the production line and yielding the final product, beer $B$. The waste, including diatomaceous earth, separated at this ninth stage, forms the fourth type of waste BW9.

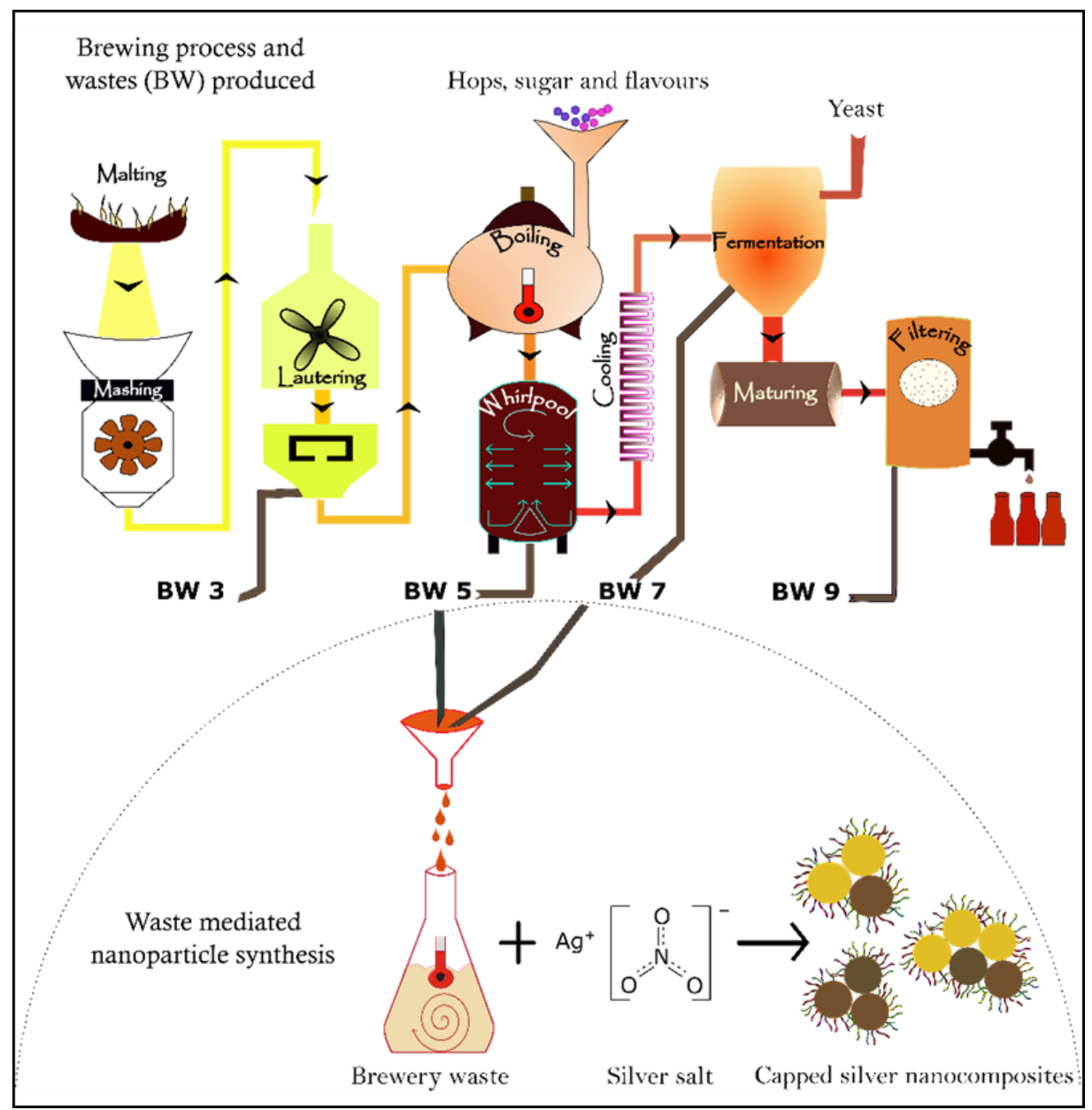

Scheme 1. Wastes (BW) produced in brewing and their valorization for nanoparticle synthesis. 
Roughly $15 \%$ of the hops constituents are retrieved in the beer, and the rest (85\%) becomes spent hop material, BW5 [7]. The BW5 waste obtained after the wort boiling process includes majorly insoluble hop materials, condensation products of hop polyphenols, wort proteins, and isomerized hop acids adsorbed on the solid surface $[8,9]$. The spent hops cannot be used as feed supplements as they contain 2-methyl-3-buten-2-ol, the product of bitter acid degradation with hypnotic-sedative properties. Therefore, spent hops have been used as fertilizers and soil conditioners, as they have high nitrogen content. They are also mixed with spent grain and used as animal fodder [7]. However, several valuable compounds can be recovered from spent hops, such as flavors, saccharides, and organic hop acids. BSY (BW7) is the second major by-product of the brewing industry that has a significant environmental impact as this waste has a large quantity of biomass ( $1 \mathrm{hl}$ of beer generates $2-4 \mathrm{~kg}$ of BSY) [10] and water which makes their management quite difficult for the brewing industry. The BW7 waste is rich in carbohydrates, proteins, amino acids, ash, and vitamins. BSY is also rich in minerals such as calcium, chromium, copper, iron, magnesium, manganese, phosphorus, potassium, selenium, and zinc [7]. Yeast's mineral content is approximately $5-10 \%$ of the cell dry weight [9]. Therefore, these brewery industry wastes are rich sources of several essential compounds that can be recycled efficiently for various applications. However, they are usually mixed with spent grains and supplied as animal fodder or used for laboratory alcohol synthesis.

Metal and metal oxide nanoparticles have been extensively researched and applied due to their unique size-dependent properties. Waste-mediated synthesis of nanoparticles has been explored over the past decade. It has the advantage of decreased use of chemical precursors and waste side-products. Several metal-based nanoparticles such as Ag, Au, Zn, $\mathrm{Cu}$, and Fe have been prepared by this method. Grape stalk waste extract has been used for producing Ag nanoparticles with application in screen-printed electrodes [11]. The reduction of silver ions to obtain silver nanoparticles has been explored using wastes such as orange peel, mango peel, and pineapple extract [12]. Furthermore, tansy fruit extracts have been used to produce silver and gold nanospheres [13]. Additionally, platinum and palladium nanoparticles have been synthesized using lignin, banana peel, tea, and coffee extracts [12]. Nanoparticles of metal oxides such as copper oxide synthesized using brown alga extract have been reported as well [14]. Although a limited number of recent research has reported the synthesis of Ag nanoparticles using beer yeast [15], the unprocessed brewery wastes still have remained unexplored in recycling applications despite being so rich in several valuable compounds.

On the other hand, orthophosphate-based nanoparticles came into the limelight for their photosensitivity in the visible region [16]. The most widely used chemical synthesis method includes a metal source and another source of orthophosphate co-precipitated to form nanoparticles. Template-assisted synthesis is yet another route explored [17]. However, alternative natural-/waste-product-mediated greener synthesis routes for silver orthophosphate nanoparticles have not yet been explored to the best of our knowledge. Moreover, the application of silver phosphates as antimicrobial agents has been limited. As we are on the verge of the 'post-antibiotic era' because of significantly increasing antimicrobial resistance, nanoparticles are essential alternatives. They attack the microbes with several different mechanisms, including direct contact with the bacterial cell wall, and therefore, the antimicrobial resistance observed for current antibiotics would not be relevant $[18,19]$. Therefore, this research focused on the possibility of utilizing waste produced in the brewing industry for the preparation of silver phosphate nanoparticles. This method is a simple, cost-, time-, and energy-efficient way of synthesizing metal phosphate nanoparticles. Herein, nanocomposites of silver were synthesized using two different brewery by-products: filtered wastes from stage 7 (BW7) and stage 5 (BW5). Characterization of the brewery wastes indicated the composition differences between BW7 and BW5. We have further studied the effect of temperature and time of synthesis on nanoparticles' structure, elemental composition, morphology, and their surface chemical states. The nanoparticles 
were applied as antibacterial agents against a Gram-negative bacteria strain to understand the influence of their chemical composition on the antibacterial activity.

\section{Materials and Methods}

\subsection{Materials}

Silver nitrate (99.9\% purity) was purchased from Avantor Performance Materials S.A. Poland (former POCH S.A., Gliwice, Poland). Brewery waste was provided by Jabłonowo Brewery, Wólka Kossowska, Poland. Brewery wastes and silver nitrate were the precursors for nanoparticle synthesis.

\subsection{Synthesis of Nanoparticles}

The schematic of nanoparticle synthesis is shown in Scheme 1. It was a simple one-pot synthesis procedure. The unprocessed brewery wastes directly from the production line were used for nanoparticle synthesis. The brewery wastes were filtered using $150 \mathrm{~mm}$ filter paper. A measure of $50 \mathrm{~mL}$ of the filtered brewery waste (BW5 or BW7) was heated over a magnetic stirrer under constant stirring at $100 \mathrm{rpm}$ until the desired temperature $\left(25,50\right.$, and $\left.80^{\circ} \mathrm{C}\right)$ was attained. Subsequently, silver nitrate salt was added to the filtered waste to obtain the concentration of $100 \mathrm{mM}$. The reaction was carried out at various times $(10,30$, or $120 \mathrm{~min})$. The $\mathrm{pH}$ of BW7 was 4.85 , and that of BW5 was 4.3 at the beginning of the synthesis. The $\mathrm{pH}$ of the solutions decreased slightly after synthesis to $\sim 4$ (BW7) and $\sim 3.5$ (BW5), possibly due to the removal of capping agents from the brewery waste. The solution was then centrifuged at 10,000 rpm in a MPW 351R centrifuge (MPW MED. INSTRUMENTS, Warsaw, Poland) after cooling it for up to $10 \mathrm{~min}$ to $\sim 35^{\circ} \mathrm{C}$. The supernatant was discarded, and distilled water was used to wash the nanoparticles two times. Then, the nanoparticles were kept for drying for $24 \mathrm{~h}$ at $\sim 40{ }^{\circ} \mathrm{C}$ in an air oven. Finally, the powder form of nanoparticles was used for further analyses. The nanoparticles were characterized for their bulk phase and elemental composition and surface morphology and composition. Furthermore, their antimicrobial activity was studied to understand the effect of nanocomposite composition on inhibition and bactericidal efficiency.

\subsection{Instruments and Analysis Methods}

The brewery wastes were examined for the presence of elements, total nitrogen, total polyphenols, total carbohydrates, total fermenting carbohydrates (fructose, glucose, maltose+ sucrose, maltotriose, sulfate $\left(\mathrm{SO}_{4}{ }^{2-}\right)$, total organic carbon (TOC), and other chemical compounds. The elemental content of the majority of elements was examined by a conventional combustion method. $\mathrm{Cl}$ was examined using the potentiometric-argentometric method by titration with $\mathrm{AgNO}_{3}$ standard, whereas the total nitrogen content was determined using the Kjeldahl titration method (PN-A-04018:1975) [20]. The content of total polyphenols was determined using the spectrophotometric method (PN-A-7909313:2000) [21]. The total carbohydrate content was determined using the spectrophotometric method according to 9.26, 8.14 Analytica EBC, 2.7.3 MEBAK (2013) [22]. The content of total fermenting carbohydrates was determined using high-performance liquid chromatography with refractometric detection (HPLC/RID) and external standards according to 9.27, 8.7 Analytica EBC, 2.7.2 MEBAK (2013) [23]. The sulfate content was determined using highperformance liquid chromatography with conductometric detection (HPLC/CD) using an external standard according to 2.22.1 MEBAK (2013) [24]. The total organic carbon was determined using the spectrometric method according to CLA/SR/26/2012 [25]. The chemical compounds present were determined using high-performance liquid chromatography and mass spectrometry (HPLC-MS).

Fourier-transform infrared (FT-IR) spectra of brewery waste liquid solutions and powdered nanoparticles were recorded under dry nitrogen at atmospheric pressure and under $5 \mathrm{hPa}$, respectively, using the Fourier Vertex $80 \mathrm{~V}$ spectrophotometer equipped with multi-reflection Attenuated Total Reflectance accessory-multi-ATR and DTGS detector (Bruker Inc., Billerica, MA, USA). The spectra were recorded using apparatus parameters 
such as the full width at half-maximum (FWHM) of $2 \mathrm{~cm}^{-1}$ and number of scans 1024 . The Empyrean D8 X-ray diffractometer (Bruker Inc., Billerica, MA, USA) was used for recording the powder X-ray diffraction (PXRD) patterns of the polycrystalline nanomaterials. This apparatus was equipped with Bragg-Brentano geometry, an X-ray tube $(\mathrm{Cu}$ $\mathrm{K} \alpha$ radiation) with $\mathrm{K} \beta$ filters goniometer in a theta-theta vertical system. The identification of chemical compounds and their phases present in the nanoparticles was achieved using X'PertHighscore Plus software. The Nova NanoSEM 450 (FEI, Hillsboro, OR, USA) scanning electron microscope (SEM) recorded images at $10 \mathrm{kV}$ high voltage and immersion imaging mode. Energy dispersive X-ray analyzer (EDX) attached to SEM was used for surface elemental mapping. A MiniPal 4 PW4025/00 Energy dispersive X-ray fluorescence (EDXRF) spectrometer (PANanalytical Inc., Malvern, UK) was used to analyze the elemental composition of nanomaterials. The X-ray photoelectron spectroscopy (XPS) measurements were carried out in an ultra-high-vacuum for surface chemical analysis using the ESA-31 electron spectrometer (home-made) [26]. The spectrometer was equipped with a hemispherical electron energy analyzer of a high relative energy resolution of $0.5 \%$ without retardation (the retarding ratio ( $\mathrm{k}$ ) can be changed from 2 up to 100), an electron gun (LEG62-VG Microtech), a home-made X-ray excitation source (Al K $\alpha$ X-rays $\mathrm{h} v=1486.67 \mathrm{eV}$ ), and an $\mathrm{Ar}^{+}$ion source of AG21 (VG Scientific). The XPS spectra were measured in the fixed retarding ratio (FRR) mode $(\mathrm{k}=4,8,16)$ at a photon incidence and electron emission angles of $70^{\circ}$ and $0^{\circ}$, respectively, with respect to the surface normal of the specimen.

\subsection{Bacterial Susceptibility Tests}

Nanocomposites synthesized after $120 \mathrm{~min}$ at 25 and $80^{\circ} \mathrm{C}$ were tested for their activity against the Gram-negative strain Escherichia coli ATCC 25922. The bacterial strain was grown overnight on Lysogeny broth (LB) agar media (Carl Roth GmbH + Co. KG, Karlsruhe, Germany). An inoculum of the strain was prepared in the Mueller Hinton (MH) broth (Becton, Dickinson and Company, Franklin Lakes, NJ, USA) by adding the colonies from the agar plates to achieve an optical density of 0.1 , corresponding to $\sim 10^{8} \mathrm{CFU} \mathrm{mL} \mathrm{m}^{-1}$. The nanoparticles were ultrasonicated using the VCX 130 ultrasonic processor at $30 \%$ amplitude for $10 \mathrm{~min}$ in the pulse mode to enable uniform dispersion. The pulse mode was used to prevent over-heating of the solution. The nutrient broth and agar media were sterilized in a Varioklav steam sterilizer (HP Medizintechnik GmbH, Oberschleissheim, Germany).

The minimum inhibitory concentration (MIC) of nanoparticles was determined as the primary parameter that would enable further advanced studies. Stock solutions of $1 \mathrm{mg} \mathrm{mL}^{-1}$ nanocomposites were prepared in $\mathrm{MH}$ nutrient broth containing $10 \%$ phosphate buffer saline (PBS). PBS enabled better dispersion of nanocomposites. Serial dilution was performed on a 96-well plate to obtain nanocomposite concentrations between 0.5 and $50 \mu \mathrm{g} \mathrm{mL}^{-1}$. The bacterial strain was then added to the 96-well plates to achieve a final concentration of $5 \times 10^{5} \mathrm{CFU} \mathrm{mL}{ }^{-1}$. After $24 \mathrm{~h}$, alamarBlue reagent (Life Technologies Europe BV, Bleiswijk, Netherlands) was added. The plates were further incubated for $2 \mathrm{~h}$, after which the absorbance value was measured using the plate reader. After MIC determination, the minimum bactericidal concentration (MBC) was determined by plating the dilutions on agar plates. Concentrations of nanocomposites higher than MIC up to 4 times were contacted with $15 \mathrm{~mL}$ bacteria inoculum $\left(10^{5}-10^{6} \mathrm{CFU} \mathrm{mL} \mathrm{m}^{-1}\right)$ of E. coli for $24 \mathrm{~h}$ in an orbital shaker incubator at $220 \mathrm{rpm}$ and $37^{\circ} \mathrm{C}$ temperature. A $50 \mu \mathrm{L}$ solution was taken from the tubes and plated after serial dilutions on agar plates. The lowest nanocomposite concentration that resulted in the absence of colonies on agar plates after $24 \mathrm{~h}$ incubation was considered the bactericidal concentration.

Furthermore, time-kill kinetics were observed at sub-MIC, MIC, and MBC concentrations between 0 and $24 \mathrm{~h}$ of nanoparticles contact with bacterial inoculum. The time-kill studies were performed by exposing a $5 \mathrm{~mL}$ inoculum $\left(10^{5}-10^{6} \mathrm{CFU} \mathrm{mL}{ }^{-1}\right)$ of $E$. coli to a defined concentration of nanocomposites in $15 \mathrm{~mL}$ centrifuge tubes for up to $24 \mathrm{~h}$. The tubes were covered with aluminum foil to prevent the interaction of nanocomposites with 
light radiation. A $50 \mu \mathrm{L}$ solution was taken from the tubes and plated after serial dilutions on agar plates. The number of colonies was counted, and the final concentration of E. coli was determined in a $1 \mathrm{~mL}$ solution. A positive control without nanoparticles was used as a reference for bacteria growth.

\section{Results}

\subsection{Brewery Wastes Analyses}

The composition and elemental analysis of brewery wastes obtained in two production stages: the fifth stage (BW5: wort precipitate) and the seventh stage (BW7: Brewer's spent yeast) are presented in Table 1. The brewery waste BW7 is richer in nitrogen, polyphenols, and sulfates as compared to BW5. BW5, disparately, has a significant content of carbohydrates and sugars. BW7 is deficient in both carbohydrates and sugars. BW7 also has high potassium, magnesium, sodium, and manganese content, whereas BW5 has significantly more phosphorous content. The influence of these composition changes is on the nanocomposite formation, discussed in detail in the Discussion section. Moreover, small amounts of iron, zinc, and copper can also be seen in brewery wastes. A similar carbon content is detected in both the wastes in total organic carbon (TOC) analysis. As the sucrose content in BW5 and BW7 was negligible, the total fermentable sugars can be equated to reducing sugars present in brewery wastes.

Table 1. Composition analysis of brewery wastes BW7 and BW5.

\begin{tabular}{|c|c|c|c|c|}
\hline \multirow{2}{*}{ Analysis } & \multirow{2}{*}{ Subtype } & \multirow{2}{*}{ Units } & \multicolumn{2}{|c|}{ Brewery Wastes } \\
\hline & & & BW7 & BW5 \\
\hline Total nitrogen & & & 7454.5 & 975.8 \\
\hline Total polyphenols & & & 181.2 & 92.65 \\
\hline Total sulfates & & & 193.03 & 119.65 \\
\hline \multirow[t]{3}{*}{ Total carbohydrates } & & & 4500 & 156700 \\
\hline & Total & $\mathrm{mg} \mathrm{L}^{-1}$ & 1600 & 115,800 \\
\hline & Fructose & & 700 & 2100 \\
\hline \multirow[t]{8}{*}{ Fermentable sugars } & Glucose & & 300 & 12,500 \\
\hline & $\begin{array}{l}\text { Maltose + } \\
\text { sucrose }\end{array}$ & & 500 & 76,500 \\
\hline & Maltotriose & & 100 & 24,700 \\
\hline & $\mathrm{K}$ & & $2710 \pm 460$ & $657 \pm 111$ \\
\hline & $\mathrm{P}$ & & $97 \pm 3.9$ & $525 \pm 20$ \\
\hline & $\mathrm{Cl}$ & & $<4$ & $365 \pm 1.0$ \\
\hline & $\mathrm{Mg}$ & & $228.3 \pm 38.8$ & $125.9 \pm 21.4$ \\
\hline & $\mathrm{Ca}$ & & $55.0 \pm 8.3$ & $69.3 \pm 10.4$ \\
\hline \multirow{7}{*}{ Elemental content } & $\mathrm{Na}$ & $\mathrm{I}-1$ & $64.0 \pm 6.4$ & $58.0 \pm 5.8$ \\
\hline & $\mathrm{Mn}$ & $\mathrm{mg} \mathrm{L}^{-1}$ & $1.64 \pm 0.13$ & $0.73 \pm 0.06$ \\
\hline & $\mathrm{Fe}$ & & $0.8 \pm 0.11$ & $0.3 \pm 0.04$ \\
\hline & $\mathrm{Zn}$ & & $2.6 \pm 0.36$ & $0.43 \pm 0.06$ \\
\hline & $\mathrm{Cu}$ & & $0.32 \pm 0.03$ & $0.08 \pm 0.01$ \\
\hline & $\mathrm{Al}$ & & $0.01 \pm 0.01$ & $0.01 \pm 0.01$ \\
\hline & $\mathrm{Ni}$ & & $<0.05$ & $<0.05$ \\
\hline Total organic carbon & & $\%$ & 7.24 & 7.78 \\
\hline
\end{tabular}

Significant differences can be observed in the FT-IR spectra of the two brewery wastes, BW7 and BW5 (Figure 1). The broad band between $\sim 3700$ and $3300 \mathrm{~cm}^{-1}$ is related to strong intramolecular H-bonded O-H stretching vibrations of polyphenols combined with the $\mathrm{N}-\mathrm{H}$ stretching vibrations for hydrogen-bonded $\mathrm{NH}$ groups. The band is more intense and slightly shifted to longer wavelengths for BW5. The broad band at $3080 \mathrm{~cm}^{-1}$ can be related to the $\mathrm{C}-\mathrm{H}$ stretching vibrations for compounds built from carbon atoms of $\mathrm{sp}^{2}$ hybridizations. The $\mathrm{C}-\mathrm{H}$ alkane stretching vibrations can be found in both wastes in the $2990-2850 \mathrm{~cm}^{-1}$ region, however, there are additional peaks with a higher intensity in BW7. 
The peaks at $1670 \mathrm{~cm}^{-1}$ and $1550 \mathrm{~cm}^{-1}$ can be attributed to amide I ( $\mathrm{C}=\mathrm{O}$ stretching with some $\mathrm{N}-\mathrm{H}$ bending) and amide II ( $\mathrm{N}-\mathrm{H}$ bending with $\mathrm{C}-\mathrm{N}$ stretching), respectively $[27,28]$. The $\mathrm{C}-\mathrm{H}$ alkane bending vibrations can be observed around 1450 and $1360 \mathrm{~cm}^{-1}$. The intense bands at $1260,1150,1075$, and $1030 \mathrm{~cm}^{-1}$ could represent $\mathrm{C}-\mathrm{O}$ vibrations or $-\mathrm{O}-\mathrm{H}$ bending of primary, secondary, and tertiary alcohols. These vibrations can also relate to the $\mathrm{C}-\mathrm{O}$ bending of the $\mathrm{C}-\mathrm{OH}$ groups in carbohydrates, especially in BW5, as it does not contain fermented alcohols [29]. Below $1000 \mathrm{~cm}^{-1}$, the out-of-plane $\mathrm{X}-\mathrm{H}$ bending $(\mathrm{X}=\mathrm{C}, \mathrm{O}, \mathrm{N})$ or $\mathrm{NH}_{2}$ rocking and wagging appear. The sharp peaks usually correspond to non-hydrogen-bonded groups. Therefore, the sharp band at $875 \mathrm{~cm}^{-1}$ observed in BW7 could correspond to the alcoholic $-\mathrm{O}-\mathrm{H}$ bending or $\mathrm{NH}_{2}$ rocking and wagging vibrations. The absence of this band in the waste obtained before the fermentation stage, BW5, could be due to the lack of yeast and fermentation products [30]. The significantly lower nitrogen content in BW5 (Table 1) supports this band assignment. The rich spectra for both wastes indicate the possibilities of alcohols, amides, and polyphenols in the composition. The functional groups can also be associated with carbohydrates (region $\sim 1150$ to $900 \mathrm{~cm}^{-1}$ ), lipids (region $\sim 2950$ to $2850 \mathrm{~cm}^{-1}$ ), and proteins (region $\sim 1690$ to $1635 \mathrm{~cm}^{-1}$ ) in the wastes along with polyphenolic compounds [27-33]. Therefore, these wastes can be used for the synthesis of nanoparticles.

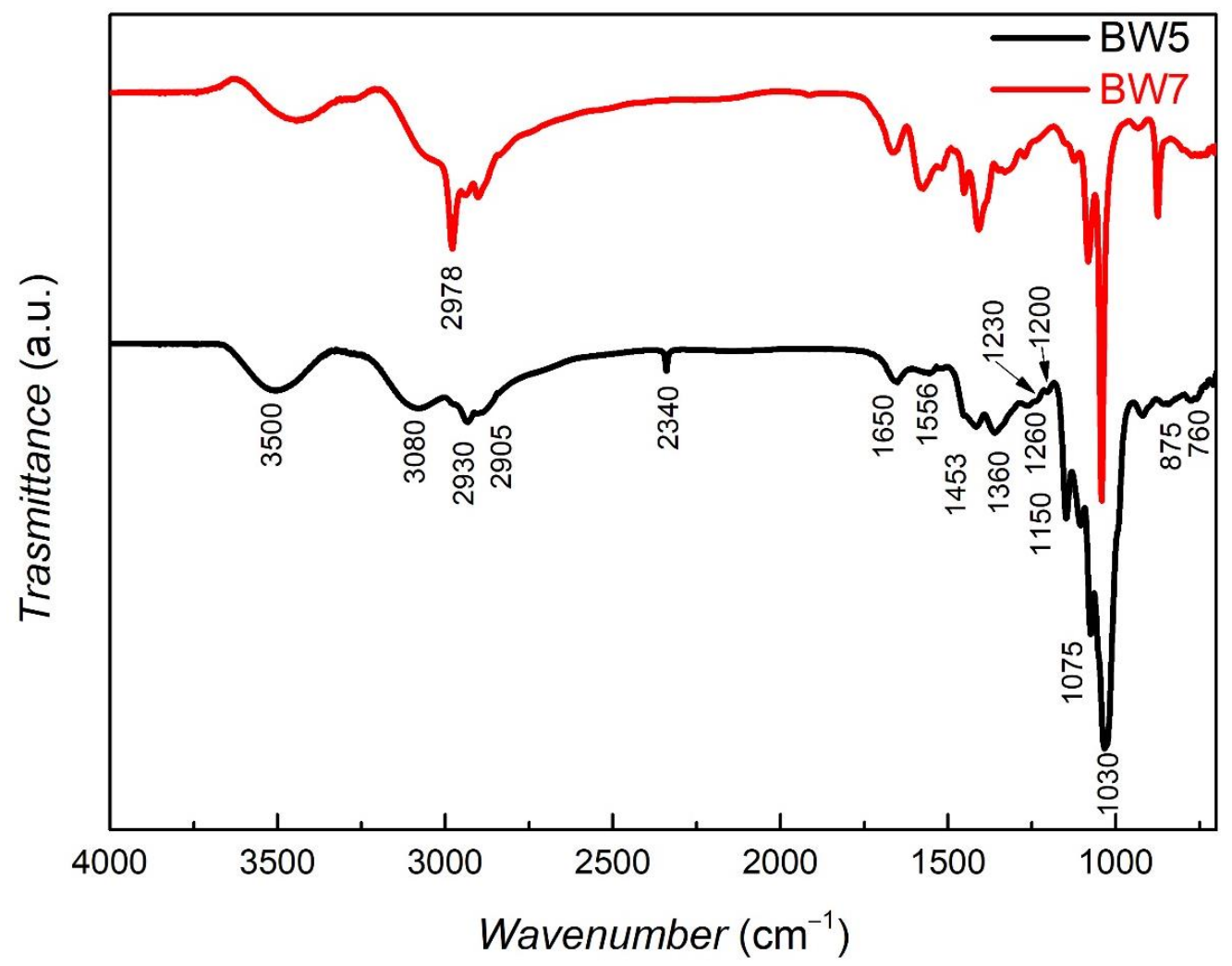

Figure 1. FT-IR spectra of brewery wastes BW7 and BW5.

\subsection{Characterization of Nanocomposites}

\subsubsection{Crystallography and Phase Analysis}

The X-ray diffraction patterns (Figure 2) provided important information on the key differences between the nanoparticles precipitated using different brewery wastes (BW5 and BW7). The PXRD patterns showed reflexes characteristic for $\mathrm{Ag}_{3} \mathrm{PO}_{4}$ (ICDD 98-002-7843), $\mathrm{AgCl}$ (ICDD 98-005-6538), and Ag (ICDD 98-060-4629) phases. The phase composition was determined from the most intensive PXRD reflexes representing every phase, i.e., (012) at $2 \theta=33.3^{\circ}$ for $\mathrm{Ag}_{3} \mathrm{PO}_{4},(002)$ at $2 \theta=32.3^{\circ}$ for $\mathrm{AgCl}$ and (111) at $2 \theta=38.1^{\circ}$ for $\mathrm{Ag}$ metal (Agmet). The method using the Reference Intensity Ratio (RIR) values with respect to corundum was applied [34]. The Scherrer's equation using a constant of 0.94 
and accounting for the same reflexes of each phase in $2 \theta$ range of $20^{\circ}-60^{\circ}$ was applied to evaluate the average values of crystallite size and the respective standard deviations, when considering more than one reflex. The results are listed in Table 2.

The brewery waste from stage 7, BW7, yielded silver orthophosphate nanoparticles $\left(\mathrm{Ag}_{3} \mathrm{PO}_{4}\right)$ (Figure 2a,c, Table 2) with reflections corresponding to the cubic structure with space group P4-3n. The characteristic $\mathrm{Ag}_{3} \mathrm{PO}_{4}$ reflexes are at $2 \theta$ values $20.9^{\circ}(011), 29.7^{\circ}$ (002), 33.3 ${ }^{\circ}(012), 36.6^{\circ}(112), 47.9^{\circ}(013), 52.8^{\circ}(222), 55.1^{\circ}(023), 57.4^{\circ}(123), 61.7^{\circ}(004)$, $72.0^{\circ}(124)$, and $87.4^{\circ}(234)$. An additional reflex at $69.98^{\circ}(024) 2 \theta$ is found in samples synthesized at $80^{\circ} \mathrm{C}$. The evolution of new reflexes and narrowing of all crystalline reflexes with increasing synthesis temperature indicated that the crystallinity of the phase enhances with increasing temperature. The crystal structure consists of a body-centered cubic lattice formed by regular isolated tetrahedral $\mathrm{PO}_{4}$. According to Ma et al. (2016), the Ag atom experiences fourfold coordination by four $\mathrm{O}$ atoms [35]. The $\mathrm{P}$ atoms have fourfold coordination surrounded by four $\mathrm{O}$ atoms, while the $\mathrm{O}$ atoms have fourfold coordination surrounded by three $\mathrm{Ag}$ atoms and one $\mathrm{P}$ atom. The polyhedron structure described by the same group consists of one $\mathrm{PO}_{4}$ tetrahedron and three tetrahedral $\mathrm{AgO}_{4}$ combined

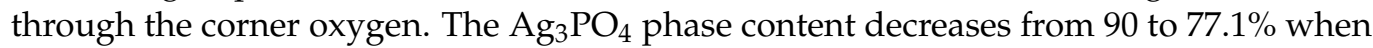
the synthesis temperature is increased up to $80{ }^{\circ} \mathrm{C}$. The crystallite size of these $\mathrm{Ag}_{3} \mathrm{PO}_{4}$ nanoparticles increased with the increasing synthesis temperature from $9.9 \pm 2.3 \mathrm{~nm}$ to $16.2 \pm 3.3 \mathrm{~nm}$.
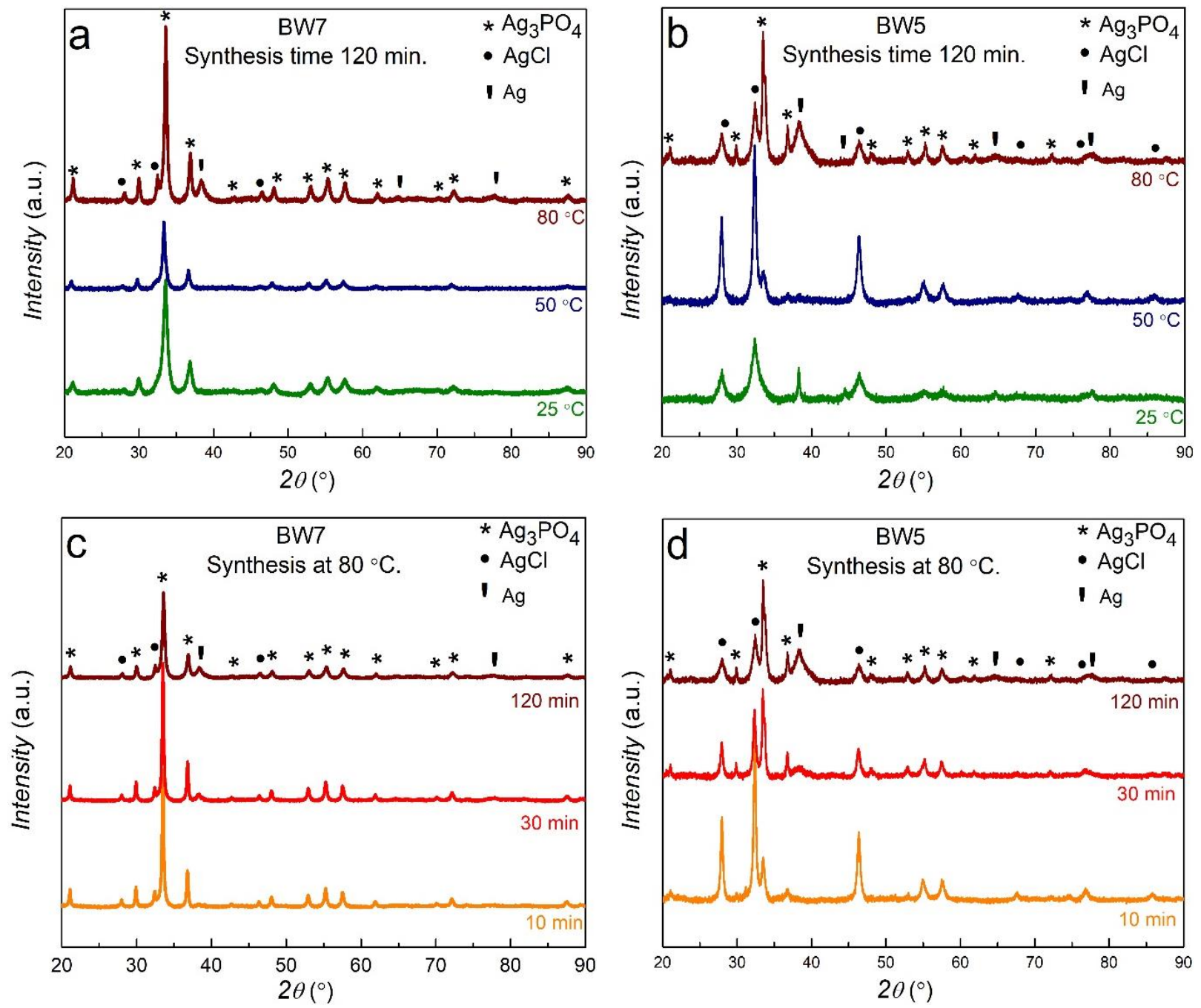

Figure 2. X-ray diffractograms of nanomaterials synthesized at different temperatures and times using brewery wastes $(\mathbf{a}, \mathbf{c})$ BW7 and $(\mathbf{b}, \mathbf{d})$ BW5. 
Table 2. Phase content and nanocrystallites size of BW7 and BW5 nanomaterials.

\begin{tabular}{|c|c|c|c|c|c|c|c|c|}
\hline & \multirow{3}{*}{$\begin{array}{c}\text { Synthesis temp., } \\
{ }^{\circ} \mathrm{C}\end{array}$} & \multirow{3}{*}{$\begin{array}{c}\text { Synthesis Time, } \\
\text { min. }\end{array}$} & \multicolumn{6}{|c|}{ PXRD Analysis } \\
\hline & & & \multicolumn{3}{|c|}{ Ag Phase Content (wt.\%) } & \multicolumn{3}{|c|}{ Nanocrystallites Size (nm) } \\
\hline & & & $\mathrm{Ag}_{3} \mathrm{PO}_{4}$ & $\mathrm{AgCl}$ & $\mathrm{Ag}_{\text {met }}$ & $\mathrm{Ag}_{3} \mathrm{PO}_{4}$ & $\mathrm{AgCl}$ & $\mathrm{Ag}_{\text {met }}$ \\
\hline BW7Ag1 & 25 & & 90.0 & 10.0 & - & $9.9 \pm 2.3$ & $5.5 \pm 3.6$ & - \\
\hline BW7Ag2 & 50 & 120 & 88.7 & 11.3 & - & $15.5 \pm 4.2$ & 7.5 & - \\
\hline BW7Ag3 & 80 & & 77.1 & 11.8 & 11.1 & $16.2 \pm 3.3$ & $16.5 \pm 5.9$ & 7.3 \\
\hline BW7Ag4 & 80 & 30 & 79.2 & 12.0 & 8.8 & $25.3 \pm 4.0$ & $26.2 \pm 5.2$ & 12.2 \\
\hline BW7Ag5 & 80 & 10 & 86.6 & 10.8 & 2.6 & $22.7 \pm 3.8$ & $21.0 \pm 8.3$ & 15.1 \\
\hline BW5Ag1 & 25 & & 5.9 & 91.5 & 2.6 & 4.8 & $4.0 \pm 0.5$ & 18.1 \\
\hline BW5Ag2 & 50 & 120 & 13.8 & 85.7 & 0.5 & 5.6 & $8.1 \pm 0.8$ & 14.0 \\
\hline BW5Ag3 & 80 & & 30.0 & 41.5 & 28.5 & $12.1 \pm 6.2$ & $6.7 \pm 0.4$ & 3.2 \\
\hline BW5Ag4 & 80 & 30 & 28.5 & 46.0 & 25.6 & $15.9 \pm 6.2$ & $10.2 \pm 1.7$ & 1.4 \\
\hline BW5Ag5 & 80 & 10 & 13.1 & 86.9 & - & $11.8 \pm 0.7$ & $11.9 \pm 1.0$ & - \\
\hline
\end{tabular}

Minor quantities (10 wt.\%) of silver chloride nanoparticles with an average crystallite size of $5.5 \pm 3.6 \mathrm{~nm}$ (Table 2) have been identified in nanocomposites synthesized at room temperature. The reflexes around $2 \theta$ values $27.8^{\circ}(111), 32.3^{\circ}(002)$, and $46.3^{\circ}(022)$ belong to silver chloride $(\mathrm{AgCl})$. The crystallinity of all three phases, $\mathrm{Ag}_{3} \mathrm{PO}_{4}, \mathrm{AgCl}$, and $\mathrm{Ag}$, increases with synthesis temperature. The $\mathrm{AgCl}$ nanoparticle phase slightly grows from 10 to $11.8 \mathrm{wt} . \%$ and the size of the crystallites grow with increasing temperature. The $\mathrm{AgCl}$ content does not significantly increase as BW7 contains a relatively insignificant amount of chlorine (Table 1). The $\mathrm{AgCl}$ has a body-centered cubic structure with a space group $\mathrm{Fm}-3 \mathrm{~m}$. When the synthesis temperature increases to $80^{\circ} \mathrm{C}, \mathrm{Ag}$ met nanoparticles are also formed, indicating that high temperature facilitates the reduction of $\mathrm{Ag}$ ions in the salt precursor silver nitrate from +1 to 0 oxidation state. Reflexes of $\mathrm{Ag}$ are present at $2 \theta$ values $38.1^{\circ}(111), 64.5^{\circ}(022)$, and $77.4^{\circ}(113)$. The $\mathrm{Ag}$ phase steadily increases at $80^{\circ} \mathrm{C}$ from 10 to 120 min synthesis time at the expense of the major phase $\mathrm{Ag}_{3} \mathrm{PO}_{4}$. The $\mathrm{AgCl}$ and $\mathrm{Ag}_{3} \mathrm{PO}_{4}$ crystallite growth is favored over nucleation with increasing synthesis temperature. The crystallite size of $\mathrm{Ag}_{3} \mathrm{PO}_{4}$ and $\mathrm{AgCl}$ increases from 10 to $30 \mathrm{~min}$ and then decreases when the synthesis time is increased to $120 \mathrm{~min}$. This unusual trend could indicate that the synthesis time affects two competing mechanisms: nucleation and growth. The size of Ag crystallites decreases with the synthesis time, indicating that nucleation is favored over this phase's growth.

The stage 5 brewery waste, BW5, diversely, gave rise to the mixed composite of majorly $\mathrm{AgCl}$. The $\mathrm{AgCl}$ phase content up to $91.5 \mathrm{wt} . \%$ could be obtained at room temperature synthesis. The $\mathrm{Ag}$ and $\mathrm{Ag}_{3} \mathrm{PO}_{4}$ nanoparticles were found in minor amounts (Figure $2 \mathrm{~b}, \mathrm{~d}$, Table 2). With time and increasing synthesis temperature, more $\mathrm{Ag}_{3} \mathrm{PO}_{4}$ nanoparticles (up to $30 \mathrm{wt} . \%$ ) and $\mathrm{Ag}$ (up to $28.5 \mathrm{wt} . \%$ ) were introduced into the composite structure. The crystallographic structures of the various nanoparticles in these composites were similar to those observed for nanoparticles obtained using BW7. The crystallite size of $\mathrm{Ag}_{3} \mathrm{PO}_{4}$ nanoparticles increases, and that of $\mathrm{Ag}$ nanoparticles decreases with increasing temperature. Temperature favors the growth of $\mathrm{Ag}_{3} \mathrm{PO}_{4}$ crystallites and nucleation of $\mathrm{Ag}$ crystallites. $\mathrm{Ag}$ nanoparticle growth at the expense of $\mathrm{AgCl}$ could be the reason for the smaller crystallite size of $\mathrm{AgCl}$ at $80^{\circ} \mathrm{C}$. The $\mathrm{Ag}$ and $\mathrm{Ag}_{3} \mathrm{PO}_{4}$ phases grow at the expense of $\mathrm{AgCl}$ with time at $80^{\circ} \mathrm{C}$ synthesis temperature. The crystallites' size of these two phases also increases with time; however, that of $\mathrm{AgCl}$ decreases. This effect is similar to that observed with synthesis temperature for $\mathrm{AgCl}$ crystallites. Synthesis time favors the growth of nanocrystallites of minor phases such as Ag and $\mathrm{Ag}_{3} \mathrm{PO}_{4}$. Silver oxides could not be observed in PXRD diffractograms, probably because their content is below the detection limit. 


\subsubsection{Elemental and Morphological Analysis}

The elemental content analysis of the samples was performed by energy dispersive $\mathrm{X}$-ray fluorescence (EDXRF). The nanomaterials obtained by using brewery wastes BW5 and BW7 contained silver $(\mathrm{Ag})$, chlorine $(\mathrm{Cl})$, phosphorus $(\mathrm{P})$, and sulfur $(\mathrm{S})$. Table 3 shows the calculated weight percentage of these elements in the samples. The area under the peak for Ag was the highest, confirming that Ag metal-based nanoparticles are formed. The Ag content is almost similar in all the BW7 nanomaterials. The slight differences are related to the growth of minor amounts of $\mathrm{Ag}$ phases (up to $11.1 \mathrm{wt} . \%$ ) with temperature and time (Table 2). The content of $\mathrm{P}$ decreases with increasing time and temperature, which is also coherent with Ag metal nanoparticle formation at higher temperatures observed in PXRD. The content of $\mathrm{Cl}$ and $\mathrm{S}$ is almost constant in all the BW7 nanomaterials. Only a minor amount of $\mathrm{Cl}$ is observed ( 1\%) coherent with the low $\mathrm{AgCl}$ phase content (up to $12 \mathrm{wt} . \%$ ) (Table 2).

Table 3. Elemental composition of BW7 and BW5 nanomaterials.

\begin{tabular}{ccccccc}
\hline & & \multirow{4}{4}{ XRF Analysis } \\
Sample & $\begin{array}{c}\text { Synthesis temp., } \\
{ }^{\circ} \mathbf{C}\end{array}$ & $\begin{array}{c}\text { Synthesis Time, } \\
\text { min. }\end{array}$ & \multicolumn{3}{c}{ Elemental Composition (wt. \%) } \\
\cline { 4 - 7 } & & & $\mathbf{A g}$ & $\mathbf{P}$ & $\mathbf{C l}$ & $\mathbf{S}$ \\
\hline BW7Ag1 & 25 & 120 & 93.5 & 4.8 & 1.0 & 0.8 \\
BW7Ag2 & 50 & & 93.7 & 4.3 & 1.1 & 0.8 \\
BW7Ag3 & 80 & 30 & 94.4 & 3.9 & 1.0 & 0.8 \\
BW7Ag4 & 80 & 10 & 94.4 & 4.0 & 1.0 & 0.6 \\
BW7Ag5 & 80 & & 93.8 & 4.2 & 1.2 & 0.8 \\
\hline BW5Ag1 & 25 & 120 & 86.5 & 5.3 & 7.7 & 0.5 \\
BW5Ag2 & 50 & & 88.4 & 2.9 & 8.1 & 0.6 \\
BW5Ag3 & 80 & 30 & 92.2 & 3.0 & 4.4 & 0.5 \\
BW5Ag4 & 80 & 10 & 91.6 & 2.9 & 5.0 & 0.6 \\
BW5Ag5 & 80 & 87.6 & 2.9 & 8.8 & 0.6 \\
\hline
\end{tabular}

In BW5 nanomaterials, the content of Ag increases from 86.5 to $92.2 \mathrm{wt} . \%$ with increasing synthesis temperature. The growth of a larger amount of $\mathrm{Ag}_{\text {met }}$ nanoparticles in the composite (up to $28.5 \mathrm{wt} . \%$ ) observed in PXRD is concurrent with this increase. Additionally, at $80{ }^{\circ} \mathrm{C}$ synthesis temperature, the yield is increased with time as the Ag content increases from $87.6 \%$ to $92.2 \%$. The amount of $\mathrm{Cl}$ in BW5 nanocomposites decreases with increasing temperature and time of synthesis as the formation of Ag metal nanoparticles is favored. This observation is coherent with the decrease in the $\mathrm{AgCl}$ phase observed in PXRD (Table 2). The $S$ present as traces in all the samples is included in the organic layer stabilizing the nanoparticles proved further by XPS analysis.

The morphology of $\mathrm{Ag}_{3} \mathrm{PO}_{4}$-rich sample BW7Ag1 obtained using BW7 at $25{ }^{\circ} \mathrm{C}$ (Figure $3 a, b$ ) shows globular structures which appear to be made of several smaller balls. $\mathrm{As} \mathrm{AgCl}$ and $\mathrm{Ag}$ increase in the structures with increasing synthesis temperature (BW7Ag3), the flakey aggregated layers are fused with balls as observed in the areas marked in red (Figure 3c,d). The size of these globular structures ranges from $\sim 10$ to $350 \mathrm{~nm}$ in BW7 nanocomposites. BW5 nanocomposite at $25^{\circ} \mathrm{C}$ (BW5Ag1) shows aggregated layers, characteristic of $\mathrm{AgCl}$ along with some small balls and globules (Figure $3 \mathrm{e}-\mathrm{g}$ ). With increasing $\mathrm{Ag}_{3} \mathrm{PO}_{4}$ in the structure, fused morphology similar to $\mathrm{BW7}$ nanocomposites is observed (Figure $3 \mathrm{~h}, \mathrm{i}$ ). In Figure $3 \mathrm{i}$, the particles observed have a surface similar to the $\mathrm{Ag}_{3} \mathrm{PO}_{4}$ balls in BW7 nanocomposites. The elemental mapping in Figure S1a-d (Supplementary Information-SI) indicates that the elemental distribution of $\mathrm{Ag}, \mathrm{Cl}$, and $\mathrm{P}$ on the surface of the nanocomposites is sufficiently homogeneous. This indicates that the nanoparticles' morphological changes in shapes and sizes are due to the incorporation of certain phases in the structure; however, these phases are not present independently but rather as a mixed phase composite. 

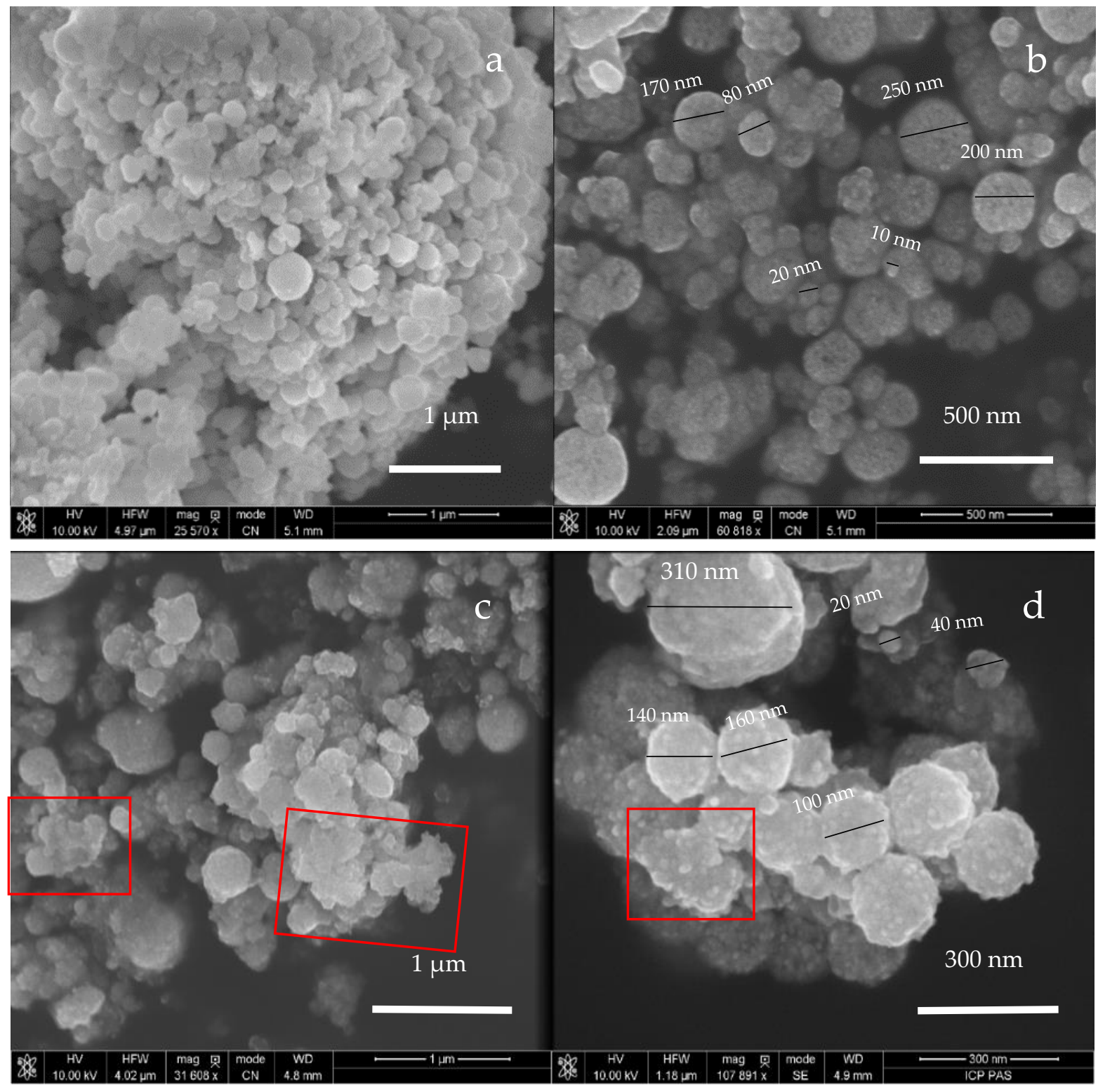

Figure 3. Cont. 

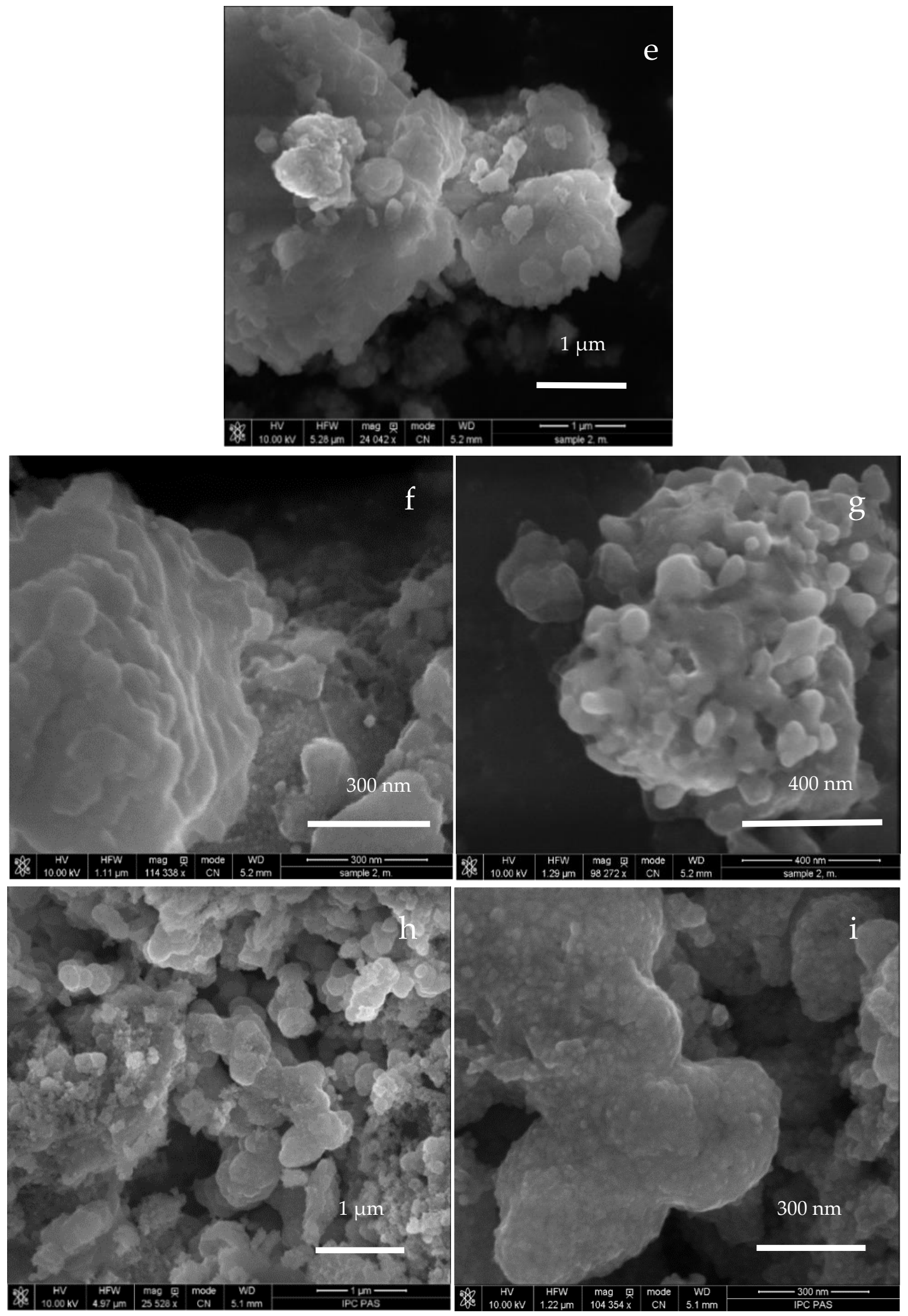

Figure 3. SEM images of nanomaterials synthesized after 120 min using brewery wastes $\mathrm{BW} 7$ at $(\mathbf{a}, \mathbf{b}) 25^{\circ} \mathrm{C}(\mathrm{BW} 7 \mathrm{Ag} 1)$, (c,d) $80^{\circ} \mathrm{C}$ (BW7Ag3) and BW5 at (e-g) $25^{\circ} \mathrm{C}$ (BW5Ag1), (h,i) $80^{\circ} \mathrm{C}$ (BW5Ag3). 


\subsubsection{Chemical Analysis}

Both sets of nanocomposites show a broad band between 3500 and $3000 \mathrm{~cm}^{-1}$, representing the stretching vibrations of the hydrogen-bonded $\mathrm{OH}$ group of polyphenols, although the relative intensities of these peaks vary depending on the nanocomposite (Figure 4). This broad band can also be attributed to the $\mathrm{N}-\mathrm{H}$ stretching vibration of amide. This vibration is stronger in BW5 nanocomposites, indicating a higher amount of surface-bound hydroxyl groups and other hydrogen-bonded functional groups. The shift in this band to lower frequencies in nanoparticles compared to its position in brewery wastes (Figure 1) is related to the complexation of the functional groups to nanoparticles. In addition, several sharp peaks observed between 2840 and $3000 \mathrm{~cm}^{-1}$ belong to symmetric and asymmetric $\mathrm{C}-\mathrm{H}$ stretching vibrations from alkanes in various chemical environments. These stretching vibrations are also significantly intense in BW5 nanocomposites, but not so in the case of BW7 nanocomposites. Interestingly, the C-H-containing compounds are better visible in the BW7 waste than in BW5 (Figure 1). Moreover, the dominant band in this region for BW7 waste is $2978 \mathrm{~cm}^{-1}$ indicating the presence of compounds with $-\mathrm{CH}_{3}$ moieties. On the other hand, BW7 nanocomposites exhibit only very weak bands in this region. BW5 nanocomposites show important bands in this region, and the dominant peaks at $2915-2920$ and $2850 \mathrm{~cm}^{-1}$ are indicative of mainly $-\mathrm{CH}_{2}-$ moieties presence. The amide I and II vibrations observed at $1640 \mathrm{~cm}^{-1}$ and $1540 \mathrm{~cm}^{-1}$ related to peptide-protein binding are also from the brewery wastes. These vibrations are intense in nanocomposites synthesized using BW5 and very weak in BW7 nanocomposites. This contradicts the situation observed in the case of wastes, where the intensity of those bands is weaker in the case of BW5 than BW7 (Figure 1). Considering the nanoparticle composition, one could infer that the protein-peptide adsorption is more predominant in the case of $\mathrm{AgCl}$ nanoparticles than in the case of $\mathrm{Ag}_{3} \mathrm{PO}_{4}$ ones. The intense band between 1030 and $1040 \mathrm{~cm}^{-1}$ representing $\mathrm{C}-\mathrm{O}$ vibration is observed in the $\mathrm{BW} 5$ nanocomposites representing the functional groups in BW5 (Figure 1). The capping of BW5 nanocomposites shows a higher number of functional groups in the FT-IR analysis, indicating that these materials' surface composition is richer than the BW7 nanocomposites. The functional group vibrations observed for these nanoparticles are from the brewery wastes BW7 and BW5, indicating a successful capping of the nanoparticles. Furthermore, the shifts in the frequencies of these vibrations in nanoparticles (Figure 4) compared to that in the brewery wastes (Figure 1) indicate a high level of complexation of the functional groups with the nanoparticles. Not all functional groups aid in the capping of nanoparticles, and depending on the brewery waste, different groups have been attached to the nanoparticles' surface. It seems that the binding of protein-peptide, as well as polyphenols, is more preferred on the surface of $\mathrm{AgCl}$ nanoparticles.

Additional vibrations relating to $\mathrm{Ag}_{3} \mathrm{PO}_{4}$ and silver oxides can also be observed in the nanocomposites. The peak observed for BW7 and BW5 nanocomposites at frequencies of $\sim 520-550 \mathrm{~cm}^{-1}$ represent Ag-O stretching modes. The band around $550 \mathrm{~cm}^{-1}$ is also attributed to a bending vibration of $\mathrm{O}=\mathrm{P}-\mathrm{O}$, whereas the band at $\sim 960 \mathrm{~cm}^{-1}$ to the asymmetric stretching of the OP-O bridge [35-37]. These modes of $\mathrm{PO}_{4}{ }^{3-}$ are visibly sharp for BW7 nanocomposites at all temperatures and time, providing evidence of $\mathrm{Ag}_{3} \mathrm{PO}_{4}$ as the major phase. Characteristic vibration modes for $\mathrm{Ag}_{3} \mathrm{PO}_{4}$ become more prominent with the increasing temperature and time for $\mathrm{BW} 5$ nanocomposites, indicating the growth of $\mathrm{Ag}_{3} \mathrm{PO}_{4}$ in the nanocomposite. There is also a shift in the vibration frequency from 520 to $540 \mathrm{~cm}^{-1}$ as phosphate groups grow in the BW5 nanocomposites with increasing synthesis temperature. The lower frequency of vibration for $\mathrm{BW} 5$ nanocomposite at $80^{\circ} \mathrm{C}$, as compared to $\mathrm{BW7}$ nanocomposite, is because $\mathrm{Ag}_{3} \mathrm{PO}_{4}$ is a minor phase in it. Therefore, it has a more complex environment around it that influences its vibration. 

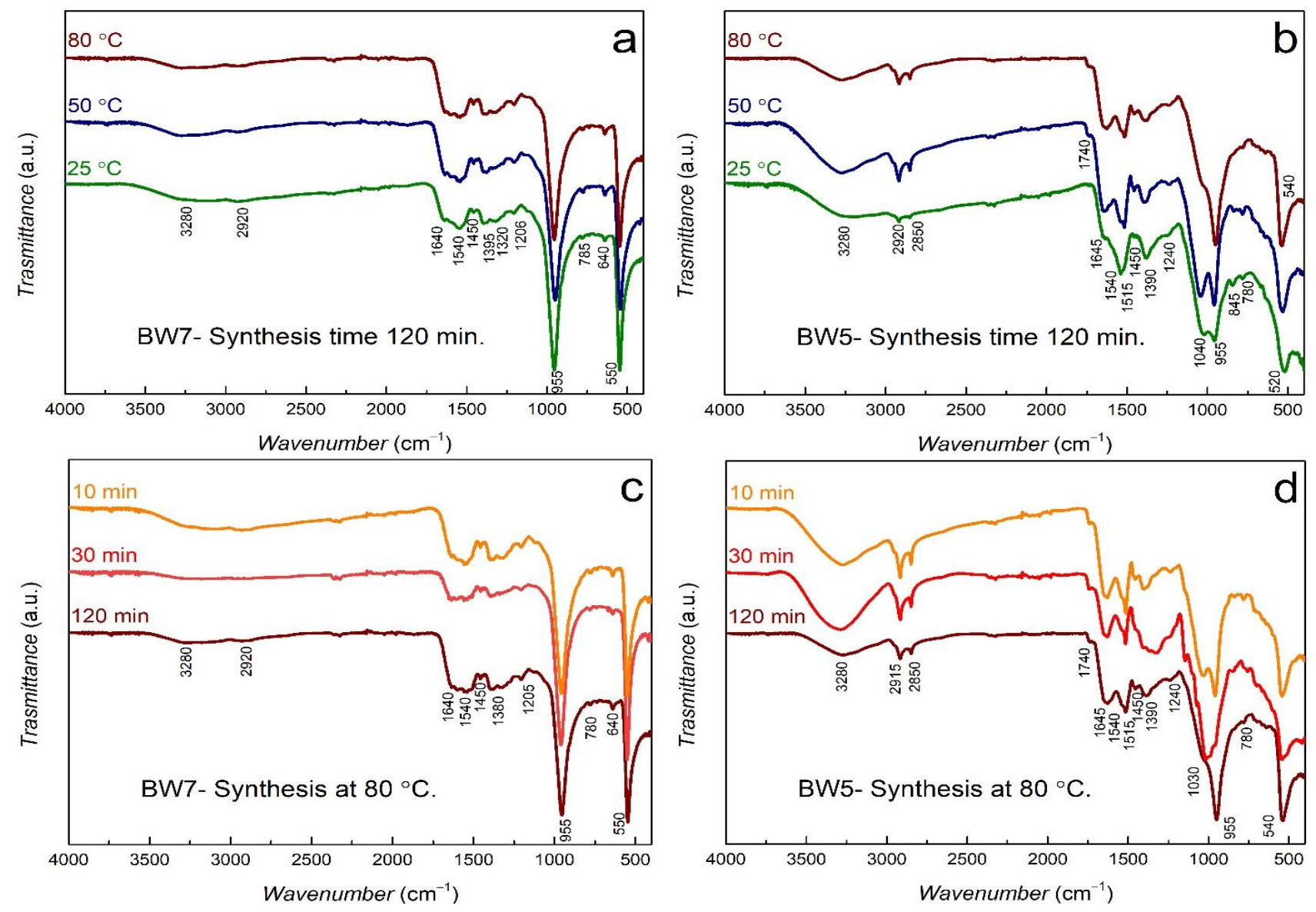

Figure 4. FT-IR spectra of nanomaterials synthesized at different temperatures and times using brewery wastes (a,c) BW7 and $(\mathbf{b}, \mathbf{d})$ BW5.

The survey XPS spectra of BW7 and BW5 nanomaterials are shown in Figure S2. The quantification of the surface atomic content in the specimens (Table 4) was carried out accounting for the area under $\mathrm{Ag} 3 \mathrm{~d}, \mathrm{C} 1 \mathrm{~s}, \mathrm{O} 1 \mathrm{~s}, \mathrm{~N} 1 \mathrm{~s}, \mathrm{P} 2 \mathrm{p}, \mathrm{S} 2 \mathrm{p}$, and $\mathrm{Cl} 2 \mathrm{p}$ photoelectron peaks originating from the XPS experiments after using Tougaard's correction for the background from inelastically scattered electrons [38]. The XPS MultiQuant software $[39,40]$ evaluated surface atomic content, accounting for Scofield photoionization cross-sections [41], electron inelastic scattering, and analyzer transmission function.

Table 4. Surface weight composition of BW7 and BW5 nanocomposites by XPS.

\begin{tabular}{|c|c|c|c|c|c|c|c|c|c|}
\hline \multirow{3}{*}{ Sample } & \multirow{3}{*}{$\begin{array}{l}\text { Synthesis temp., } \\
{ }^{\circ} \mathrm{C}\end{array}$} & \multirow{3}{*}{$\begin{array}{c}\text { Synthesis Time, } \\
\text { min. }\end{array}$} & \multicolumn{7}{|c|}{ XPS Analysis } \\
\hline & & & \multicolumn{7}{|c|}{ Surface Elemental Composition (wt.\%) } \\
\hline & & & $\mathrm{C}$ & $\mathrm{O}$ & Ag & $\mathbf{N}$ & $\mathbf{P}$ & S & $\mathrm{Cl}$ \\
\hline BW7Ag1 & 25 & & 24.0 & 14.0 & 50.7 & 5.0 & 3.0 & 1.3 & 2.0 \\
\hline BW7Ag2 & 50 & 120 & 24.6 & 14.7 & 50.5 & 4.4 & 2.5 & 1.4 & 1.9 \\
\hline BW7Ag3 & 80 & & 19.5 & 12.5 & 59.3 & 3.3 & 3.4 & 1.4 & 0.6 \\
\hline BW7Ag4 & 80 & 30 & 19.6 & 11.6 & 61.5 & 3.3 & 2.5 & 1.1 & 0.4 \\
\hline BW7Ag5 & 80 & 10 & 20.6 & 12.7 & 57.4 & 3.9 & 3.6 & 1.2 & 0.6 \\
\hline BW5Ag1 & 25 & & 25.7 & 15.6 & 46.8 & 2.6 & 4.1 & 1.3 & 3.9 \\
\hline BW5Ag2 & 50 & 120 & 33.3 & 12.9 & 43.2 & 2.8 & 3.6 & 1.0 & 3.2 \\
\hline BW5Ag3 & 80 & & 26.9 & 11.2 & 48.8 & 2.3 & 3.5 & 4.2 & 3.1 \\
\hline BW5Ag4 & 80 & 30 & 60.2 & 19.1 & 18.0 & 1.2 & 0.9 & - & 0.6 \\
\hline BW5Ag5 & 80 & 10 & 41.2 & 14.2 & 36.2 & 2.6 & 2.3 & 0.7 & 2.8 \\
\hline
\end{tabular}


The binding energy (BE) values calibration was performed for all the photoelectron spectra, i.e., $\mathrm{Ag} 3 \mathrm{~d}_{5 / 2-3 / 2}, \mathrm{C} 1 \mathrm{~s}, \mathrm{O} 1 \mathrm{~s}, \mathrm{~N} 1 \mathrm{~s}, \mathrm{~S} 2 \mathrm{p}, \mathrm{P} 2 \mathrm{p}$, and $\mathrm{Cl} 2 \mathrm{p}$, considering the Ag $3 \mathrm{~d}_{5 / 2-3 / 2}$ predominant component resulting from the PXRD patterns (Table 2).

The surface of BW7 and BW5 nanocomposites shows the presence of $\mathrm{Ag}\left(\mathrm{Ag} 3 \mathrm{~d}_{5 / 2-3 / 2}\right)$, $\mathrm{C}(\mathrm{C} 1 \mathrm{~s}), \mathrm{O}(\mathrm{O} 1 \mathrm{~s}), \mathrm{N}(\mathrm{N} 1 \mathrm{~s}), \mathrm{Cl}(\mathrm{Cl} 2 \mathrm{p}), \mathrm{P}(\mathrm{P} 2 \mathrm{p})$, and $\mathrm{S}(\mathrm{S} 2 \mathrm{p})$. The elemental content depends on nanomaterial synthesis conditions and the brewery waste. The ratio of $\mathrm{C}$ to Ag is larger for BW5 nanocomposites, indicating a thicker carbon overlayer on silver nanoparticles composite (Figure S3a). At higher temperatures, the larger ratio of $\mathrm{C}$ to $\mathrm{O}$ for BW5 nanocomposites indicates oxygen deficiency of its carbon overlayer, contrary to BW7 nanocomposites (Figure S3b). Simultaneously, with increasing temperature, the ratio of $\mathrm{Ag}$ to $\mathrm{O}$ increases. This increase is relatively lower for BW5 nanocomposites, indicating the formation of a higher amount of silver oxides and the incorporation of a higher amount of carbon-oxygen groups when BW5 is used (Figure S3c).

The BE values for all elements present were evaluated after binding energy scale calibration and averaging the respective values for BW7 and BW5 nanocomposites prepared at different temperatures and synthesis times. These BE values confirm the presence of the chemical compounds. Nitrogen $(\mathrm{N} 1 \mathrm{~s} \mathrm{BE}=399.4 \pm 0.1 \mathrm{eV})$ indicates an amino group $\left(\mathrm{C}-\mathrm{NH}_{2}\right)$ [42] present in protein structures. Chlorine $(\mathrm{Cl} 2 \mathrm{p} \mathrm{BE}=198.6 \pm 0.1 \mathrm{eV})$ is identified as $\mathrm{AgCl}$ [42]. In $\mathrm{BW} 7$ nanocomposites with $\mathrm{Ag}_{3} \mathrm{PO}_{4}$ as the predominant phase, the phosphorous peak $(\mathrm{P} 2 \mathrm{p} \mathrm{BE}=132.9 \pm 0.1 \mathrm{eV})$ indicates phosphate $\left(\mathrm{PO}_{4}\right)$, phosphite $\left(\mathrm{PO}_{2}\right)$, or phosphine $(\mathrm{P}=\mathrm{N}=\mathrm{P})$ groups [42]. In $\mathrm{BW} 5$ nanocomposites with $\mathrm{AgCl}$ as the predominant phase, phosphorous peak $(\mathrm{P} 2 \mathrm{p} \mathrm{BE}=133.3 \pm 0.1 \mathrm{eV})$ indicates hydrogen phosphate $\left(\mathrm{HPO}_{4}\right)$, diphosphate $\left(\mathrm{P}_{2} \mathrm{O}_{7}\right)$, triphosphate $\left(\mathrm{P}_{3} \mathrm{O}_{10}\right)$, dioxide diphosphorus $\left(\mathrm{H}_{4} \mathrm{P}_{2} \mathrm{O}_{2}\right)$, or phosphate in the organic matrix, e.g., methyl phosphate $\left(\mathrm{PO}_{3} \mathrm{CH}_{3}\right)$ [42]. The chemical state of sulfur indicates two forms, which depend on the nanoparticle synthesis temperature and time. The chemical form of sulfur at $\mathrm{BE}=162.9 \pm 0.1 \mathrm{eV}$ indicates sulfur linked in an organic environment, whereas the chemical form at $\mathrm{BE}=168.0 \pm 0.1 \mathrm{eV}$ indicates sulfonyl $\left(\mathrm{SO}_{2}\right)$, sulfonate $\left(\mathrm{SO}_{3}\right)$, or sulfate $\left(\mathrm{SO}_{4}\right)$ groups [42]. This last form of sulfur starts occurring between 50 and $80^{\circ} \mathrm{C}$.

Comparison of elementary weight content in bulk and at the surface resulting from EDXRF and XPS analyses for Ag, P, Cl, and S, where the XPS results from Table 4 are normalized to 100 percent, is provided in Figure S4. No significant differences in elemental bulk and surface content are observed. The increasing Ag content is observed with increasing temperature and synthesis time, contrary to decreasing $\mathrm{P}, \mathrm{Cl}$, and $\mathrm{S}$ content.

The Ag $3 d_{5 / 2-3 / 2}, C$ s, and $\mathrm{O} 1 \mathrm{~s}$ spectra were fitted to Gaussian-Lorentzian asymmetric components after Tougaard inelastic background subtraction [38] using the XPSPeakfit software [43]. The following binding energy (BE) values for $\mathrm{Ag} 3 \mathrm{~d}_{5 / 2}$ spectrum were considered in the fitting procedure of $\mathrm{Ag} 3 \mathrm{~d}_{5 / 2-3 / 2}$ spectra to determine the surface content of $\mathrm{Ag}$ chemical states: $367.8 \mathrm{eV}$ for $\mathrm{Ag}_{3} \mathrm{PO}_{4}$ [44,45]; $368.1 \mathrm{eV}$ for $\mathrm{AgCl}$ [46]; $368.3 \mathrm{eV}$ for $\mathrm{Ag}_{\text {met }}$ [47,48]; and $367.3 \mathrm{eV}$ for $\mathrm{Ag}$ oxidized structures such as $\mathrm{Ag}_{2} \mathrm{O}, \mathrm{AgO}, \mathrm{AgOH}[47,48]$. The fitting proceeded with constant ratios of full width at half maximum (FWHM) for different $\mathrm{Ag}$ phases. The presence of $\mathrm{Ag}_{2} \mathrm{O}$ was reported at $\mathrm{BE}$ shifted towards smaller values with respect to $\mathrm{Ag}_{\text {met }}$ by 0.5-0.6 eV ( $\left.\mathrm{BE}=367.7-367.8 \mathrm{eV}\right)$ and $\mathrm{AgO}$ and $\mathrm{AgOH}$ structures at $\mathrm{BE}$ shifted respectively by $0.9-1.0 \mathrm{eV}(\mathrm{BE}=367.4-367.3 \mathrm{eV})[47,48]$. Additionally, Ag-glucose structures were reported at $\mathrm{BE}$ shifted towards smaller $\mathrm{BE}$ with respect to $\mathrm{Ag}_{\text {met }}$ by about $1 \mathrm{eV} \mathrm{[49].} \mathrm{To} \mathrm{obtain} \mathrm{the} \mathrm{accurate} \mathrm{fitting} \mathrm{results,} \mathrm{the} \mathrm{additional} \mathrm{peak} \mathrm{at} \mathrm{BE}$ smaller than that for Ag oxidized structures were included, where its $\mathrm{BE}$ value resulted from the fitting procedure. The fitting results of $\mathrm{Ag} 3 \mathrm{~d}_{5 / 2-3 / 2}, \mathrm{C} 1 \mathrm{~s}$, and $\mathrm{O} 1 \mathrm{~s}$ are presented in Figure S5a-c, respectively.

The results from the fitting of the weight content of Ag chemical states are listed in Table 5. No $\mathrm{Ag}_{\mathrm{met}}$ is observed at the surface of BW7 and BW5 nanocomposites. The surface shows $\mathrm{Ag}_{3} \mathrm{O}_{4}, \mathrm{AgCl}$, and $\mathrm{Ag}$ oxidized states $\left(\mathrm{Ag}_{2} \mathrm{O}, \mathrm{AgO}, \mathrm{AgOH}\right)$ and the peak at $\mathrm{BE}=364.09 \pm 0.11 \mathrm{eV}(\mathrm{BW7})$ and $\mathrm{BE}=363.8 \pm 0.3 \mathrm{eV}$ (BW5), which is interpreted as AgO-polymer state. This AgO-polymer chemical state resulting from AgO- 
carbohydrate/polyphenol/amino structures linked through hydrogen bonds is manifested in BE shifted towards smaller $\mathrm{BE}$ values than $\mathrm{Ag}$ oxides and $\mathrm{AgOH}$. Its $\mathrm{BE}$ value depends on carbohydrates, polyphenols, and total nitrogen content forming amino groups in brewery wastes. The higher content of carbohydrates and sugars in BW5 nanocomposites (Table 1), where the synthesis conditions using the $\mathrm{BW} 5$ waste promote $\mathrm{AgCl}$ formation, leads to a larger $\mathrm{BE}$ shift with respect to $\mathrm{Ag}_{\text {met }}$ and provides a smaller ratio of $\mathrm{AgO}$-polymer to $\mathrm{Ag}$ oxidized forms (Table 5). The respective BE shift is smaller in BW7 nanocomposites, where the synthesis conditions predominantly led to the $\mathrm{Ag}_{3} \mathrm{PO}_{4}$ chemical state. The larger ratio of AgO-polymer to Ag oxidized forms indicates the more facile formation of AgO-polymer state over $\mathrm{Ag}$ oxides and $\mathrm{AgOH}$. This suggests different organometallic structures linking Ag oxides and organic material originating from amino groups, polyphenols, carbohydrates, and sugars present in both wastes and differentiated by their content (Table 1).

Table 5. Comparison of surface Ag chemical state content in BW7 and BW5 nanocomposites.

\begin{tabular}{|c|c|c|c|c|c|c|}
\hline \multirow[b]{3}{*}{ Sample } & \multirow[b]{3}{*}{$\begin{array}{l}\text { Synthesis temp., } \\
{ }^{\circ} \mathrm{C}\end{array}$} & \multirow[b]{3}{*}{$\begin{array}{c}\text { Synthesis Time, } \\
\text { min. }\end{array}$} & \multicolumn{4}{|c|}{ Ag Chemical State (wt. $\%)-A g ~ 3 d_{5 / 2-3 / 2}$} \\
\hline & & & AgO-polymer & $\mathrm{Ag}_{2} \mathrm{O}, \mathrm{AgO}, \mathrm{AgOH}$ & $\mathrm{Ag}_{3} \mathrm{PO}_{4}$ & $\mathrm{AgCl}$ \\
\hline & & & $\begin{array}{c}\text { BE (eV) } \\
364.09 \pm 0.11 \\
(\mathrm{BW}) \\
363.8 \pm 0.3(\mathrm{BW} 5)\end{array}$ & $\begin{array}{c}\mathrm{BE}(\mathrm{eV}) \\
367.30\end{array}$ & $\begin{array}{c}\text { BE }(e V) \\
367.8\end{array}$ & $\begin{array}{c}\text { BE }(\mathrm{eV}) \\
368.1\end{array}$ \\
\hline BW7Ag1 & 25 & & 3.35 & 0.25 & 42.75 & 4.35 \\
\hline BW7Ag2 & 50 & 120 & 4.21 & - & 40.72 & 5.57 \\
\hline BW7Ag3 & 80 & & 5.81 & 0.49 & 45.52 & 7.48 \\
\hline BW7Ag4 & 80 & 30 & 5.98 & 0.7 & 49.35 & 5.47 \\
\hline BW7Ag5 & 80 & 10 & 5.57 & - & 47.51 & 4.32 \\
\hline BW5Ag1 & 25 & & 3.82 & 2.32 & 2.74 & 37.92 \\
\hline BW5Ag2 & 50 & 120 & 3.52 & 2.51 & 0.71 & 36.47 \\
\hline BW5Ag3 & 80 & & 3.72 & 7.01 & 14.73 & 23.34 \\
\hline BW5Ag4 & 80 & 30 & 0.88 & 0.57 & 3.0 & 13.56 \\
\hline BW5Ag5 & 80 & 10 & 3.09 & - & 4.36 & 28.76 \\
\hline
\end{tabular}

The comparison of Ag phase weight content resulting from the PXRD and XPS analyses as temperature and time of synthesis dependence for BW7 and BW5 nanocomposites is shown in Figure S6a-d respectively. The XPS results show the content normalized to 100 percent. The $\mathrm{BW} 7$ nanocomposites containing the predominant $\mathrm{Ag}_{3} \mathrm{PO}_{4}$ phase exhibited decreased $\mathrm{Ag}_{3} \mathrm{PO}_{4}$ phase content accompanied by increasing $\mathrm{AgCl}$ phase. The $\mathrm{Ag}$ oxides, $\mathrm{AgOH}$, and $\mathrm{AgO}$-polymer phases also decreased with increasing synthesis temperature (Figure S6a). The synthesis at $80{ }^{\circ} \mathrm{C}$ decreased $\mathrm{Ag}_{3} \mathrm{PO}_{4}$ phase content, accompanied by increasing $\mathrm{AgCl}, \mathrm{Ag}$ oxides $/ \mathrm{AgOH}$, and stable $\mathrm{AgO}$-polymer forms on the surface with synthesis time (Figure $\mathrm{S6c}$ ). The $\mathrm{BW} 5$ nanocomposites containing primarily $\mathrm{AgCl}$ phase exhibited a decrease of $\mathrm{AgCl}$, accompanied by increasing $\mathrm{Ag}_{3} \mathrm{PO}_{4}, \mathrm{Ag}$ oxides $/ \mathrm{AgOH}$, and $\mathrm{AgO}-$ polymer forms (Figure $\mathrm{S6b}$,d). In BW7 nanocomposites, the AgO-polymer content is remarkably higher than $\mathrm{Ag}$ oxides/ $\mathrm{AgOH}$, contrary to $\mathrm{BW} 5$ nanocomposites. The bulk and surface content of $\mathrm{AgCl}$ and $\mathrm{Ag}_{3} \mathrm{PO}_{4}$ phases are in reasonable agreement; however, the surface shows a large amount of $\mathrm{Ag}$ oxidized structures such as $\mathrm{Ag}$ oxides, $\mathrm{AgOH}$, and Ag oxides linked to polyphenols, carbohydrates and/or amino groups via hydrogen bonds forming a kind of organometallic structure.

For the $\mathrm{C} 1 \mathrm{~s}$ spectra, the following $\mathrm{BE}$ resulting from the applied calibration using $\mathrm{Ag} 3 \mathrm{~d}_{5 / 2-3 / 2}$ spectra were applied: $284.4 \pm 0.1 \mathrm{eV}$ for $\mathrm{C} \mathrm{sp}{ }^{2}$ hybridizations, $285.3 \pm 0.1 \mathrm{eV}$ for $\mathrm{C} \mathrm{sp}^{3}$ hybridizations, $286.5 \pm 0.1 \mathrm{eV}$ for hydroxyl group $\mathrm{C}-\mathrm{OH}, 287.5 \pm 0.1 \mathrm{eV}$ for carbonyl group $-\mathrm{C}=\mathrm{O}[46,50]$. The carboxyl group $\mathrm{COOH}$ is not present in the investigated samples. For the $\mathrm{O} 1 \mathrm{~s}$ line, the following $\mathrm{BE}$ were obtained: $531.2 \pm 0.2 \mathrm{eV}$ for $\mathrm{C}=\mathrm{O}$, $532.5 \pm 0.1 \mathrm{eV}$ for $\mathrm{C}-\mathrm{O}$ and $529.9 \pm 0.2$ for $\mathrm{Ag}$ oxidized states [50,51]. The atomic contents of oxygen groups $(\mathrm{C}-\mathrm{OH}, \mathrm{C}=\mathrm{O})$ and $\mathrm{Ag}$ - oxidized chemical state resulting from the fitting 
of $\mathrm{O}$ 1s spectra are in agreement with their respective atomic contents resulting from the fitting of $\mathrm{C} 1 \mathrm{~s}(\mathrm{C}-\mathrm{OH}, \mathrm{C}=\mathrm{O})$ and $\mathrm{Ag} 3 \mathrm{~d}_{5 / 3-3 / 2}(\mathrm{Ag}-\mathrm{O})$ spectra. The carbon overlayer thickness on $\mathrm{Ag}$ nanoparticles was evaluated from $\mathrm{Ag} 3 \mathrm{~d}_{5 / 2-3 / 2}$ spectra using Tougaard Quases-Analyze software, where the surface morphology parameters are reflected in the shape of the inelastic background in the vicinity of photoelectron transition and its intensity [52]. Assuming a Buried Layer (BL) model of uniform overlayer and inelastic mean free path (IMFP) of $\mathrm{Ag}_{3 \mathrm{~d} 5 / 2-3 / 2}$ photoelectron attenuated in carbon overlayer, i.e., $3.1 \mathrm{~nm}$ [53], the subtraction of the inelastic background provides the value of overlayer thickness (Figure S7a,b). The results of C 1s spectra fitting representing the content of different carbon forms and carbon overlayer thickness in nanocomposites are presented in Table 6. The overlayer thickness dependence with temperature and synthesis time for BW7 and BW5 nanocomposites agree with the C to Ag ratio (Figure S3a), indicating a relatively thinner overlayer for BW7 nanocomposites. Simultaneously, the carbon overlayer of BW7 nanocomposites is oxygen-enriched (Figure S3b) due to the larger content of Ag-polymer chemical state and contains smaller content of Ag oxides (Figure S3c) than BW5 nanocomposites.

Table 6. Comparison of surface C chemical state content and overlayer thickness in BW7 and BW5 nanocomposites.

\begin{tabular}{|c|c|c|c|c|c|c|c|}
\hline \multirow{3}{*}{ Sample } & \multirow{3}{*}{$\begin{array}{l}\text { Synthesis } \\
\text { temp., }{ }^{\circ} \mathrm{C}\end{array}$} & \multirow{3}{*}{$\begin{array}{l}\text { Synthesis } \\
\text { Time, min. }\end{array}$} & \multicolumn{4}{|c|}{ C Chemical State (wt.\%)-C 1s } & \multirow{3}{*}{$\begin{array}{c}\text { XPS } \\
\text { QUASES-Tougaard } \\
\text { BL Model } \\
\text { Overlayer } \\
\text { Thickness (̊̊) }\end{array}$} \\
\hline & & & $C \mathrm{sp}^{2}$ & $C s p^{3}$ & $\mathrm{C}-\mathrm{OH}$ & $\mathrm{C}=\mathrm{O}$ & \\
\hline & & & $\begin{array}{c}\text { BE (eV) } \\
284.4 \pm 0.1\end{array}$ & $\begin{array}{c}\text { BE (eV) } \\
285.3 \pm 0.1\end{array}$ & $\begin{array}{c}\text { BE (eV) } \\
286.5 \pm 0.1\end{array}$ & $\begin{array}{c}\text { BE (eV) } \\
287.5 \pm 0.1\end{array}$ & \\
\hline BW7Ag1 & 25 & \multirow{3}{*}{120} & 9.78 & 8.96 & 0.55 & 4.71 & 20.7 \\
\hline BW7Ag2 & 50 & & 14.2 & 3.92 & 3.76 & 2.72 & 24.2 \\
\hline BW7Ag3 & 80 & & 11.37 & 4.64 & 3.49 & - & 18.0 \\
\hline BW7Ag4 & 80 & 30 & 12.46 & 4.11 & 3.03 & - & 17.5 \\
\hline BW7Ag5 & 80 & 10 & 13.0 & 3.88 & 3.52 & - & 17.5 \\
\hline BW5Ag1 & 25 & \multirow{3}{*}{120} & 10.36 & 9.57 & 2.03 & 3.74 & 23.0 \\
\hline BW5Ag2 & 50 & & 24.38 & 2.87 & 2.87 & 3.18 & 24.5 \\
\hline BW5Ag3 & 80 & & 17.60 & 4.04 & 2.13 & 3.13 & 23.9 \\
\hline BW5Ag4 & 80 & 30 & 41.75 & 7.52 & 7.52 & 3.41 & 37.0 \\
\hline BW5Ag5 & 80 & 10 & 31.12 & 3.93 & 2.86 & 3.29 & 32.5 \\
\hline
\end{tabular}

The BW7 and BW5 nanocomposites contain different hydroxyl and carbonyl groups content due to differences in synthesis conditions (temperature and time) (Table 6). The capping of BW5 nanocomposites shows a larger number of functional carbon-oxygen groups, indicating that these materials' surface composition is richer than the BW7 nanocomposites. This observation is in agreement with the FT-IR analysis (Figure 4). The surface of BW7 nanocomposites shows $\mathrm{C}-\mathrm{OH}$ groups predominantly, whereas BW5 nanocomposites contain $\mathrm{C}-\mathrm{OH}$ and $\mathrm{C}=\mathrm{O}$ groups in all samples. In both nanomaterials, $50{ }^{\circ} \mathrm{C}$ synthesis temperature favors increasing $\mathrm{C} \mathrm{sp}$ at the expense of $\mathrm{C} \mathrm{sp}{ }^{3}$. The synthesis time (10-120 $\mathrm{min}$.) at $80^{\circ} \mathrm{C}$ leads to carbon amorphization not affecting the content of $\mathrm{C}-\mathrm{OH}$ and $\mathrm{C}=\mathrm{O}$ groups remarkably. The synthesis temperature $\left(25-80^{\circ} \mathrm{C}\right)$ repairs $\mathrm{C} \mathrm{sp}{ }^{3}$ defects and builds $\mathrm{C}-$ $\mathrm{OH}$ groups. Amorphization of carbon in nanoparticles is related to increasing thickness of overlayers, whereas carbonization is related to decreasing thickness. The overlayer thickness in BW5 nanocomposites exceeds that in BW7 nanocomposites, which may also be due to a larger content of carbohydrates and fermentable sugars (Table 1) taking part in the formation of this overlayer. For BW5 nanomaterials, the thickness increases with increasing synthesis time from 10 to $30 \mathrm{~min}$ and then decreases with further synthesis time, whereas the synthesis temperature does not change it remarkably. No remarkable change is observed in overlayer thickness with the time of synthesis for BW7 nanocomposites. 


\subsubsection{Bacterial Susceptibility Testing}

Susceptibility of a Gram-negative strain Escherichia coli (E. coli ATCC 25922) to nanocomposites synthesized after $120 \mathrm{~min}$ reaction (BW7Ag1, BW7Ag3, BW5Ag1, and BW5Ag3) were studied. These nanocomposites were chosen to include a broad spectrum of composition. The minimum inhibitory concentration (MIC) of nanocomposites synthesized using BW7 at 25 and $80^{\circ} \mathrm{C}$ was $9.375 \mu \mathrm{g} \mathrm{mL}{ }^{-1}$ (Table 7). However, the nanoparticles synthesized using BW5 at 25 and $80^{\circ} \mathrm{C}$ showed varied influence on the inhibition of bacterial strain. The nanocomposite synthesized at $25^{\circ} \mathrm{C}$ (BW5Ag1) was slightly more lethal for the bacterial strain than the nanocomposite synthesized at $80^{\circ} \mathrm{C}$ (BW5Ag3).

Table 7. Minimum inhibitory concentration (MIC) of nanocomposites synthesized using BW7 and BW5.

\begin{tabular}{cccc}
\hline \multirow{2}{*}{ Sample } & $\begin{array}{c}\text { Synthesis temp., } \\
{ }^{\circ} \mathbf{C}\end{array}$ & $\begin{array}{c}\text { Synthesis Time, } \\
\text { min. }\end{array}$ & MIC $\left(\mu \mathbf{g ~ m L}^{-\mathbf{1}}\right)$ \\
\cline { 1 - 2 } BW7Ag1 & 25 & & Escherichia coli \\
BW7Ag3 & 80 & \multirow{2}{*}{120} & 9.375 \\
\hline BW5Ag1 & 25 & & 9.375 \\
BW5Ag3 & 80 & & 12.5 \\
\hline
\end{tabular}

BW7 nanocomposites (BW7Ag1 and BW7Ag3) at MIC concentration $\left(9.375 \mu \mathrm{gL}^{-1}\right.$ ) inhibited bacterial growth entirely up to $12 \mathrm{~h}$, and then slight growth was observed between 12 and $24 \mathrm{~h}$ (Figure 5a,b). It could indicate a tolerance developed in the bacterial strain to the nanoparticles or the inability of the nanoparticles to continue the inhibition mechanism. BW5 nanocomposite at $25^{\circ} \mathrm{C}$ (BW5Ag1) completely killed the tested bacteria at MIC (Figure $5 \mathrm{c}$ ). Therefore, at $12.5 \mu \mathrm{g} \mathrm{mL} \mathrm{m}^{-1}$, no colonies were observed on agar plates even after $24 \mathrm{~h}$ of contact between nanoparticles and the bacterial inoculum. However, at concentrations lower than $12.5 \mu \mathrm{g} \mathrm{mL}^{-1}$, the nanocomposite inhibition capacity is unable to outpace the bacteria growth beyond $8 \mathrm{~h}$. Contrastingly, the BW5 nanocomposite at $80{ }^{\circ} \mathrm{C}$ (BW5Ag3) only marginally inhibited the bacterial growth at MIC concentration $\left(12.5 \mu \mathrm{g} \mathrm{mL}^{-1}\right)$ (Figure $5 \mathrm{~d}$ ). The BW5Ag3 nanocomposite killed the inoculum only at a much higher concentration of $15.635 \mu \mathrm{g} \mathrm{mL} \mathrm{L}^{-1}$, indicating that this nanocomposite synthesized at a higher temperature using BW5 has the least antimicrobial activity. The sub-MIC concentration time-kill curves for all nanocomposites indicate that they are able to inhibit bacterial growth up to $8 \mathrm{~h}$; however, they are outpaced by the bacterial cell reproduction speed.

Time-kill kinetics indicated the rate at which the nanocomposites affect the bacterial strain E. coli (Figure 6). Low-temperature synthesis has led to more potent nanocomposites for antibacterial activity. The nanocomposites synthesized using BW7 and BW5 at $25^{\circ} \mathrm{C}$ (BW7Ag1 and BW5Ag1) take up to $1 \mathrm{~h}$ to kill the inoculum at MIC concentrations (Figure 6a). The BW7 nanocomposite at $80^{\circ} \mathrm{C}$ (BW7Ag3) takes $2 \mathrm{~h}$ for killing, and the BW5 nanocomposite at $80^{\circ} \mathrm{C}$ (BW5Ag3) does not exhibit complete killing even after $2 \mathrm{~h}$ contact time. This indicates that BW7Ag1 affects the bacteria at the fastest rate. At minimum bactericidal concentrations (MBC), all nanoparticles effectively kill the inoculum in $1 \mathrm{~h}$. However, BW7 nanocomposites (BW7Ag1 and BW7Ag3) affect at a faster rate as compared to BW 5 nanocomposites (BW5Ag1 and BW5Ag3) (Figure 6b). 

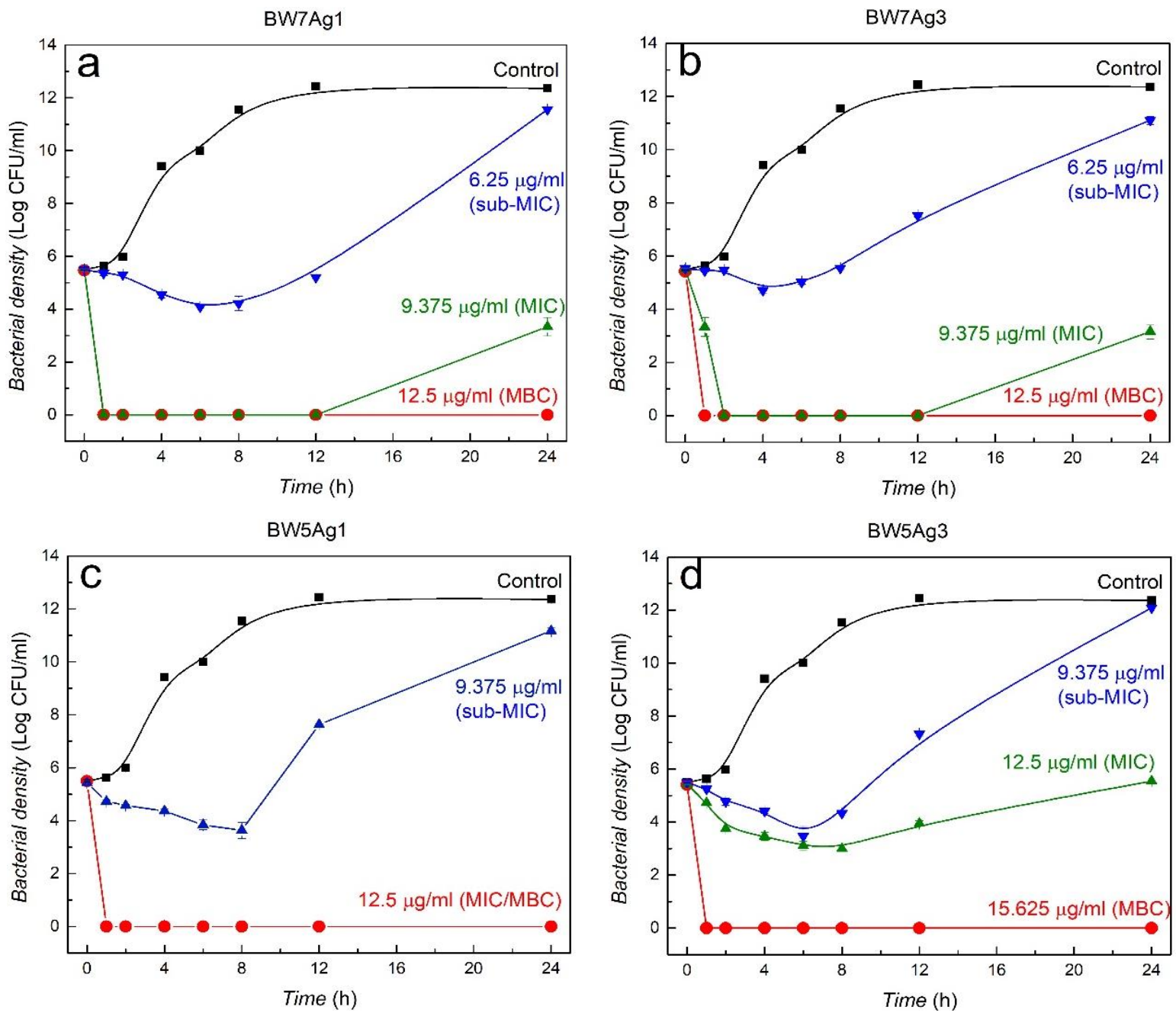

Figure 5. Time-kill curves of E. coli exposed to four different nanocomposites at different concentrations. Nanocomposites synthesized after $120 \mathrm{~min}$ reaction time using brewery wastes BW7 at (a) $25^{\circ} \mathrm{C}(\mathrm{BW} 7 \mathrm{Ag} 1)$ and (b) $80{ }^{\circ} \mathrm{C}(\mathrm{BW} 7 \mathrm{Ag} 3)$ and BW5 at (c) $25^{\circ} \mathrm{C}$ (BW5Ag1) and (d) $80{ }^{\circ} \mathrm{C}($ BW5Ag3).
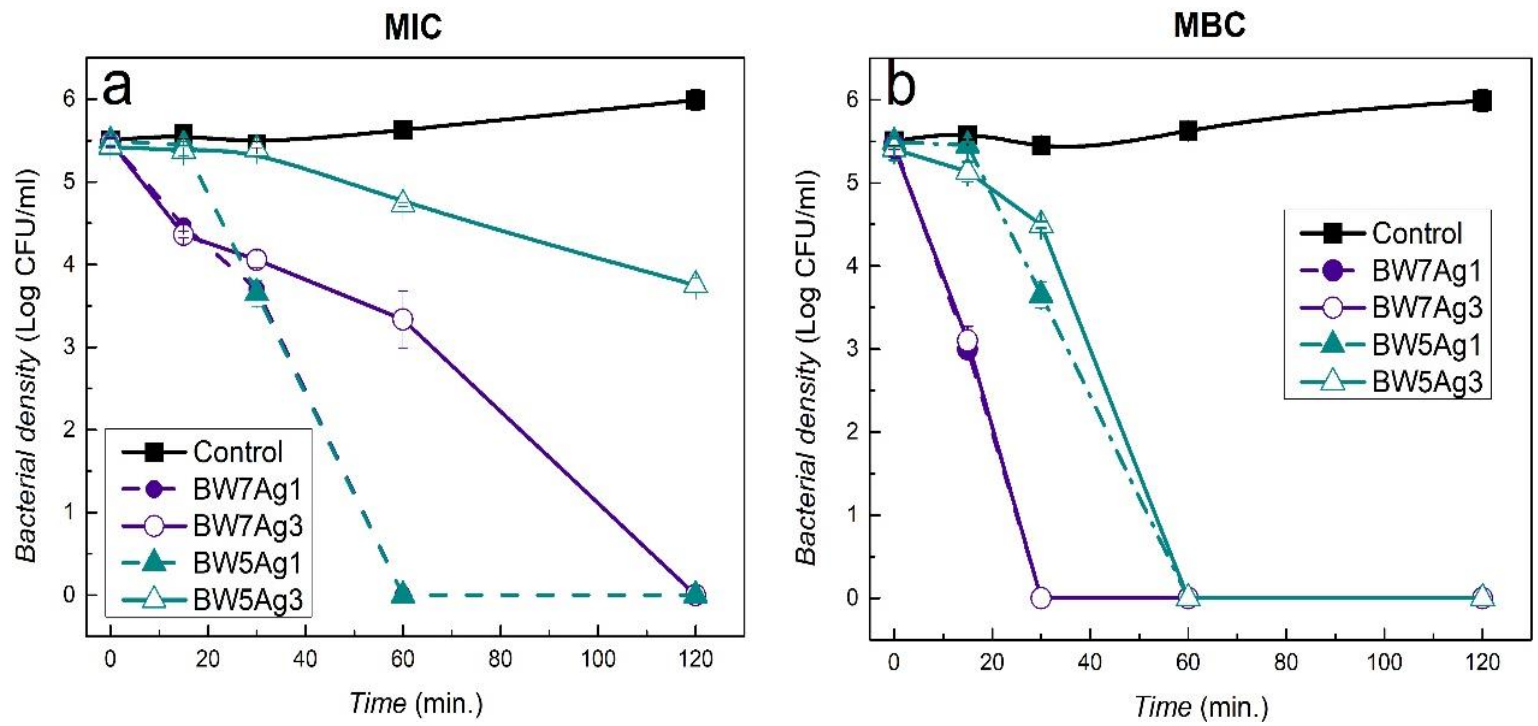

Figure 6. Time-kill kinetics of E. coli exposed to (a) MIC and (b) MBC concentrations of nanocomposites synthesized after 120 min reaction time using brewery wastes BW7 and BW5 at 25 (BW7Ag1 and BW5Ag1) and $80{ }^{\circ} \mathrm{C}(\mathrm{BW} 7 \mathrm{Ag} 3$ and BW5Ag3). 


\section{Discussion}

The temperature and time of synthesis affected the relative compositions of the three phases of silver, namely $\mathrm{Ag}_{3} \mathrm{PO}_{4}, \mathrm{AgCl}$, and $\mathrm{Ag}_{\text {met }}$, in the nanocomposites. The lack of chlorine in the BW7 and the abundance of phosphorus-based compounds cause silver phosphate formation. The presence of yeast and a nitrogen-rich environment that is highly deficient in sugars can also be instrumental in the growth of silver phosphate. Contrastingly, $\mathrm{BW} 5$ is rich in phosphorous and chlorine; therefore, competing reactions favored the growth of majorly $\mathrm{AgCl}$, and $\mathrm{Ag}_{3} \mathrm{PO}_{4}$ is incorporated as the minor component. The spontaneous formation of $\mathrm{AgCl}$ results from the exchange reaction between silver nitrate and a source of halide present in the brewery wastes. Therefore, in the presence of high amounts of $\mathrm{Cl}$ in the $\mathrm{BW5}$ waste, $\mathrm{AgCl}$ is obtained in major quantities. After the formation of $\mathrm{AgCl}$, the excess silver nitrate follows another exchange reaction with the phosphate source leading to $\mathrm{Ag}_{3} \mathrm{PO}_{4}$. As the $\mathrm{Cl}$ content in $\mathrm{BW7}$ is very low, the major phase in $\mathrm{BW} 7$ nanocomposites is predominantly $\mathrm{Ag}_{3} \mathrm{PO}_{4}$ [54]. The conversion of silver salt by both brewery wastes led to incorporating higher amounts of the minor contents in the nanocomposite structure with increasing synthesis temperature and time. Increasing the synthesis temperature can promote reactions that may not be spontaneous under room temperatures, leading to several parallel reactions yielding a composite structure. The growth of $\mathrm{Ag}_{\text {met }}$ in $\mathrm{BW} 7$ nanocomposites is favored only when the temperature is increased to $80{ }^{\circ} \mathrm{C}$ (BW7Ag3). At lower temperatures, the formation of $\mathrm{Ag}_{3} \mathrm{PO}_{4}$ is predominant. Reduction with BW5 also yields $\mathrm{Ag}_{\text {met }}$ nanoparticles with smaller crystallites size as a function of increasing synthesis temperature. The most favored reaction at $25^{\circ} \mathrm{C}$ is the formation of $\mathrm{AgCl}$. Although $\mathrm{Ag}_{3} \mathrm{PO}_{4}$ and $\mathrm{Ag}_{\text {met }}$ are also obtained at lower synthesis temperatures (BW5Ag1), the growth of the phases is promoted at $80^{\circ} \mathrm{C}$ (BW5Ag3). With increasing synthesis temperature, higher aggregation of particles is also observed for BW7 and BW5 nanocomposites. The reducing agents present in BW7 and BW5 are activated at higher temperatures, resulting in the reduction of $\mathrm{Ag}$ ions from +1 to 0 oxidation state.

Amino acids, carbohydrates, polyphenols, and sugars are well-known reducing agents responsible for reducing silver ions to silver metal and capping of nanoparticles $[55,56]$. However, different compounds present in BW7 and BW5 are responsible for nanoparticle synthesis. Sugars are known to act as potent reducing agents under alkaline conditions [57]. The added effect of hydroxyl radicals in silver reduction is also evident at alkaline $\mathrm{pH}$. Therefore, the reducing capacity of these agents is not prominent in our synthesis as the brewery wastes are acidic. The reduction by polyphenols is also affected by the system's $\mathrm{pH}$, which impacts the nanoparticle size and shape. The reduction by polyphenol at acidic $\mathrm{pH}$ leads to larger size nanoparticles [58]. Therefore, the acidic $\mathrm{pH}$ in our system led to the formation of a small amount of large-sized $\mathrm{Ag}_{\text {met }}$ nanoparticles in the composite structure primarily due to polyphenol-induced reduction.

Amino acids and proteins contain carbonyl groups that exhibit a strong affinity towards metal nanoparticles [59]. Therefore, they are some of the critical capping agents. However, although proteins are present in both wastes, the overlayer of BW5 nanocomposites contains protein groups, but the BW7 nanocomposites overlayer shows only relatively small intensity vibrations, which can be attributed to proteins. This indicates that the surface of $\mathrm{Ag}_{3} \mathrm{PO}_{4}$ and $\mathrm{AgCl}$ plays a major role in determining the organic groups that will form a part of the overlayer. The protein-peptides preferentially attach to nanocomposites with major $\mathrm{AgCl}$ in the structure. Several organic functional groups have participated in the capping. Therefore, the organic overlayer is rich in different $C$ chemical states $\left(\mathrm{Csp}^{2}, \mathrm{Csp}^{3}\right.$, $\mathrm{C}-\mathrm{O}, \mathrm{C}=\mathrm{O}$ ) and contains $\mathrm{B}, \mathrm{N}$, and $\mathrm{S}$. The overlayer of $\mathrm{BW} 5$ nanocomposites is enriched with $\mathrm{C}=\mathrm{O}$ functional group. $\mathrm{BW} 5$ nanocomposites also have a thicker overlayer capping than BW7 nanocomposites. The overlayer has the largest thickness when the synthesis temperature is $50^{\circ} \mathrm{C}$. The high temperature appears to be facilitating the attachment of organic groups to the nanoparticle surface. However, this overlayer in BW5 nanocomposites formed at higher temperatures is less oxygen-enriched than in BW7 nanocomposites. 
Although the mechanism of interaction of Ag nanoparticles on cells is complicated and till now not fully understood, there are few factors that simultaneously affect the cell: (i) adhesion on the surface of bacterial wall and membrane leading to membrane disruption, (ii) penetration into the cell, (iii) damage of intracellular organelles and biomolecules, (iv) oxidative stress due to formation of reactive oxygen species, and (v) modulation of signal transduction pathways $[60,61]$. The adhesion mechanism may result from the presence of negatively charged lipopolysaccharides forming different bonds between $\mathrm{Ag}^{+}$ions and electrostatic interaction. Penetration may proceed via water-filled channels called porins or those formed due to membrane disruption proving its better permeability. The binding of $\mathrm{Ag}^{+}$ions with the phosphorous and sulfur groups in the DNA results in condensation of DNA, preventing further replication. This ultimately prevents cell reproduction leading to microorganism death [60]. The results obtained with the $\mathrm{AgCl}$ and $\mathrm{Ag}_{3} \mathrm{PO}_{4}$ nanoparticles would pave the way to a more detailed study the dominant factors in the antimicrobial activity of silver and its compounds.

Using both the brewery wastes, the nanocomposites synthesized at 25 and $80^{\circ} \mathrm{C}$ after $120 \mathrm{~min}$ are effective antimicrobial agents. However, nanocomposites synthesized using BW7 (BW7Ag1 and BW7Ag3) are more effective at inhibiting the Gram-negative E. coli strain growth. These Ag nanoparticles are characterized by the smallest nanoparticle size, which may facilitate their penetration via cell membrane inside a cell before cell disruption due to adhesion, resulting in faster damage to cell organelles and biomolecules. Moreover, BW7Ag1 affects the bacteria faster than any other nanocomposite. It is noteworthy that the concentration of $\mathrm{Ag}^{+}$ions in solution from $\mathrm{Ag}_{3} \mathrm{PO}_{4}\left(\sim 1.3 \times 10^{-4} \mathrm{M}\right)$ is an order of magnitude higher as compared to that from $\mathrm{AgCl}\left(\sim 1.3 \times 10^{-5} \mathrm{M}\right)$ when calculated using the solubility products $\left(K_{\mathrm{sp}}\right)$ of $\mathrm{Ag}_{3} \mathrm{PO}_{4}\left(8.89 \times 10^{-17}\right)$ and $\mathrm{AgCl}\left(1.77 \times 10^{-10}\right)$ at $25^{\circ} \mathrm{C}$ [62].

Therefore, the relatively larger $\mathrm{Ag}_{3} \mathrm{PO}_{4}$ content and consequently higher content of $\mathrm{Ag}^{+}$ions in the structure could be responsible for the higher activity of BW7 nanocomposites. Additionally, the surface of BW5 nanocomposites contains different forms of phosphorous other than phosphate in contrast to BW7 nanocomposites. Moreover, the activity of BW7Ag1 could be higher also because of the smaller size, resulting in a higher surface area for adhesion. Therefore, the larger availability of $\mathrm{Ag}^{+}$ions and higher surface area could be responsible for the better antimicrobial activity of nanocomposites synthesized using BW7. Alternatively, the surface of silver phosphate nanoparticles could be more toxic for the bacterial cell than $\mathrm{AgCl}$ and $\mathrm{Ag}_{\text {met }}$. Moreover, a thinner overlayer capping $(<20 \AA)$ with a higher amount of hydrolyzed forms $\left(\mathrm{CO}^{-}\right.$and $\left.\mathrm{OH}^{-}\right)$of $\mathrm{C}-\mathrm{OH}$ groups could facilitate a better contact of the nanoparticles with the bacterial cells. The incorporation of $\mathrm{Ag}_{\mathrm{met}}$ and increase of the crystallites size of $\mathrm{Ag}_{3} \mathrm{PO}_{4}$ and $\mathrm{AgCl}$ in nanocomposite synthesized at $80^{\circ} \mathrm{C}(\mathrm{BW} 7 \mathrm{Ag} 3)$ has decreased its inhibition rate compared to nanocomposite synthesized at $25^{\circ} \mathrm{C}$. Furthermore, BW5 nanocomposites (BW5Ag1 and BW5Ag3) exhibit a relatively lower antimicrobial activity, and both have higher amounts of $\mathrm{Ag}$ met in the structure. This indicates that $\mathrm{Ag}_{\text {met }}$ is not the most effective component for the inhibition of bacterial growth. The large size of $\mathrm{Ag}_{\text {met }}$ particles could be the reason for this lowering of the antibacterial effect as they would not be able to penetrate the cell wall. Additionally, the $\mathrm{Ag}_{\text {met }}$ increases at the expense of $\mathrm{Ag}_{3} \mathrm{PO}_{4}$ or $\mathrm{AgCl}$, thereby decreasing the active material content. Therefore, the nanocomposite synthesized at $80^{\circ} \mathrm{C}(\mathrm{BW} 5 \mathrm{Ag} 3)$ has the least antimicrobial activity as it has the highest $\mathrm{Ag}_{\mathrm{met}}$ content in its structure. Additionally, these nanocomposites have a thicker overlayer capping $(>20 \AA)$ and are enriched with sp ${ }^{2}$ hybridized carbon groups that could be crucial in decreasing the interactions between the bacterial cells and nanoparticles. Overall, nanocomposite systems could be better than nanoparticles of a single-phase because of their combined synergistic effect against bacterial strains, thereby decreasing the probability of bacterial resistance.

Successful eco-friendly one-pot syntheses of Ag nanocomposites containing silver phosphate in a short time and low temperature were performed. Brewery wastes were used as agents to obtain the nanocomposites. It has to be noted that the nanocomposite characteristics are reproducible with repeated synthesis. The obtained nanocomposites 
can be applied as antimicrobial agents in air and water disinfection by filtration and disinfecting contaminated surfaces. Further studies are being carried out to evaluate the biocompatibility of these nanocomposites, enabling the application of these materials in the food and medicine industries.

\section{Conclusions}

- Nanocomposites of mainly $\mathrm{Ag}_{3} \mathrm{PO}_{4}$ and minor amounts of $\mathrm{AgCl}$ and $\mathrm{Ag}_{\text {met }}$ were obtained using BW7. BW5, disparately, converted the silver salt to mainly $\mathrm{AgCl}$ with minor amounts of $\mathrm{Ag}_{3} \mathrm{PO}_{4}$ and $\mathrm{Ag}_{\text {met }}$. The reduction of $\mathrm{Ag}^{+}$ions is promoted only at higher temperatures.

- Nanocomposites with different ratios of $\mathrm{Ag}_{3} \mathrm{PO}_{4}, \mathrm{AgCl}$, and $\mathrm{Ag}_{\text {met }}$ can be obtained by varying the synthesis temperature and time. The highest $\mathrm{Ag}_{3} \mathrm{PO}_{4}$ content $(90 \mathrm{wt} . \%)$ was obtained using BW7 in room temperature synthesis for $120 \mathrm{~min}$.

- The organic surface capping was rich in functional groups observed in the brewery wastes. The thickness of the organic layer was $\sim 15-40 \AA$. BW7 nanocomposites contain a thinner capping than BW5 nanocomposites.

- Increasing the synthesis temperature led to the incorporation of higher amounts of the minor components in the nanocomposite structures.

- The nanocomposites differ in their inhibition and bactericidal activity depending on their composition and surface organic overlayer. BW7 nanocomposites exhibited a better antibacterial activity.

\section{Patents}

The Institute of Physical Chemistry of the Polish Academy of Sciences has applied for a Polish provisional patent (P.433717/PK7364KZ).

Supplementary Materials: The following are available online at https:/ /www.mdpi.com/article/10 .3390/nano11102659/s1, Figure S1a: Elemental mapping of BW7Ag1 nanocomposite. Figure S1b: Elemental mapping of BW7Ag3 nanocomposite. Figure S1c: Elemental mapping of BW5Ag1 nanocomposite. Figure S1d: Elemental mapping of BW5Ag3 nanocomposite. Figure S2: The XPS survey spectra of BW7 and BW5 nanomaterials synthesized at different temperature and time conditions. Figure S3a: Comparison of C to Ag weight ratio for BW7 and BW5 nanomaterials dependent on synthesis (a) temperature and (b) time at $80^{\circ} \mathrm{C}$. Figure S3b: Comparison of $\mathrm{C}$ to $\mathrm{O}$ weight ratio for $\mathrm{BW7}$ and BW5 nanomaterials dependent on synthesis (a) temperature and (b) time at $80^{\circ} \mathrm{C}$. Figure S3c: Comparison of $\mathrm{Ag}$ to $\mathrm{O}$ weight ratio for BW7 and BW5 nanomaterials dependent on synthesis (a) temperature and (b) time at $80^{\circ} \mathrm{C}$. Figure S4: Comparison of elementary weight composition resulting from EDXRF and XPS spectra of nanomaterials synthesized at different temperatures and times using brewery wastes $(a, c)$ BW7 and $(b, d)$ BW5. Figure S5a: The XPS Ag 3d5/2-3/2 spectra recorded from BW7 and BW5 nanomaterials synthesized at different temperature and time conditions fitted using Gaussian-Lorentzian asymmetric functions to different atomic chemical states. Figure S5b: The XPS C 1s spectra recorded from BW7 and BW5 nanomaterials synthesized at different temperature and time conditions fitted using Gaussian-Lorentzian asymmetric functions to different atomic chemical states. Figure S5c: The XPS O 1s spectra recorded from BW7 and BW5 nanomaterials synthesized at different temperature and time conditions fitted using Gaussian-Lorentzian asymmetric functions to different atomic chemical states. Figure S6: Comparison of weight and normalized phase content resulting from XRD and XPS spectra, respectively, in nanomaterials synthesized at different temperatures and time using brewery wastes (a,c) BW7 and (b,d) BW5. Figure S7a: Results of Ag 3d5/2/3-2 spectra analysis using QUASES-Analyze software and Buried Layer (BL) model for BW7 nanomaterials at different synthesis temperatures and times at $80^{\circ} \mathrm{C}$. Figure S7b: Results of $\mathrm{Ag} 3 \mathrm{~d} 5 / 2 / 3-2$ spectra analysis using QUASES-Analyze software and Buried Layer (BL) model for BW5 nanomaterials at different synthesis temperatures and times at $80^{\circ} \mathrm{C}$. 
Author Contributions: Conceptualization: A.J.S. and N.V.R. Data curation: A.J.S. and N.V.R. Formal analysis: A.J.S., N.V.R., A.R., B.L. and P.B. Funding acquisition: B.L., K.R.N., J.T. and L.K. Investigation: A.J.S., N.V.R., J.T., P.B., D.M. and M.Ł.R. Methodology: A.J.S., N.V.R. and A.R. Resources: B.L., J.T. and L.K. Validation: A.J.S., N.V.R., A.R., B.L. and K.R.N. Visualization: A.J.S. and N.V.R. Writing一original draft: A.J.S. and N.V.R. Writing—review and editing: A.J.S., N.V.R., B.L., P.B., A.R., K.R.N., J.T., L.K., D.M. and M.Ł.R. The authors A.J.S. and N.V.R. share equal contributions in this article. All authors have read and agreed to the published version of the manuscript.

Funding: This publication is part of a project that has received funding from the European Union's Horizon 2020 research and innovation programme under the Marie Skłodowska-Curie grant agreement No. 711859. In addition, scientific work funded from the financial resources for science in the years 2017-2022 was awarded by the Polish Ministry of Science and Higher Education to implement an international co-financed project. The authors (L.K., J.T., B.L.) would like to acknowledge the support of the project between the Polish Academy of Sciences and the Hungarian Academy of Sciences (2020-2022). The author (J.T.) acknowledges the support by the European Regional Development Fund and Hungary in the frame of the project GINOP-2.2.1-15-2016-00012.

Data Availability Statement: The data are available in the data storage systems in the Research group 18 at the Institute of Physical Chemistry Polish Academy of Sciences, Warsaw, Poland.

Acknowledgments: The authors would like to thank Jabłonowo Brewery, Wólka Kosowska, Poland, for providing the brewery by-products for nanoparticle synthesis.

Conflicts of Interest: The authors declare no conflict of interest.

\section{References}

1. Fillaudeau, L.; Blanpain-Avet, P.; Daufin, G. Water, wastewater and waste management in brewing industries. J. Cleaner Prod. 2006, 14, 463-471. [CrossRef]

2. Thiel, P.G.; Du Toit, P.J. The chemical composition of a brewery waste. J. Inst. Brew. 1965, 71, 6. [CrossRef]

3. Moshtagh, B.; Hawboldt, K.; Zhang, B. Optimization of biosurfactant production by Bacillus Subtilis N3-1P using the brewery waste as the carbon source. Environ. Technol. 2019, 40, 3371-3380. [CrossRef]

4. Stefanello, F.S.; Dos Santos, C.O.; Bochi, V.C.; Fruet, A.P.B.; Soquetta, M.B.; Dorr, A.C.; Nornberg, J.L. Analysis of polyphenols in brewer's spent grain and its comparison with corn silage and cereal brans commonly used for animal nutrition. Food Chem. 2018, 239, 385-401. [CrossRef] [PubMed]

5. Barbosa-Pereira, L.; Pocheville, A.; Angulo, I.; Paseiro-Losada, P.; Cruz, J.M. Fractionation and purification of bioactive compounds obtained from a brewery waste stream. Biomed. Res. Int. 2013, 2013, 408491. [CrossRef]

6. Brewing Beer: The Brewing Process. Available online: https://www.braeuamberg.at/en/brewing-process/ (accessed on 1 June 2020).

7. Fărcaş, A.C.; Socaci, S.A.; Mudura, E.; Dulf, F.V.; Vodnar, D.C.; Tofană, M.; Salanță, L.C. Exploitation of Brewing Industry Wastes to Produce Functional Ingredients. In Brewing Technology; IntechOpen: London, UK, 2017. [CrossRef]

8. Corbo, M.R.; Bevilacqua, A.; Petruzzi, L.; Casanova, F.P.; Sinigaglia, M. Functional Beverages: The Emerging Side of Functional Foods. Compre. Rev. Food Sci. Food Saf. 2014, 13, 1192-1206. [CrossRef]

9. Handbook of Brewing; Priest, F.G.; Stewart, G.G., Eds.; Taylor \& Francis Group CRC press: Boca Raton, FL, USA, 2006.

10. Hellborg, L.; Piskur, J. Yeast Diversity in the Brewing Industry. In Beer in Health and Disease Prevention; Preedy, V.R., Ed.; Academic Press: London, UK, 2008.

11. Bastos-Arrieta, J.; Florido, A.; Perez-Rafols, C.; Serrano, N.; Fiol, N.; Poch, J.; Villaescusa, I. Green Synthesis of Ag Nanoparticles Using Grape Stalk Waste Extract for the Modification of Screen-Printed Electrodes. Nanomaterials 2018, 8, 946. [CrossRef]

12. Ghosh, P.R.; Fawcett, D.; Sharma, S.B.; Poinern, G.E.J. Production of High-Value Nanoparticles via Biogenic Processes Using Aquacultural and Horticultural Food Waste. Materials 2017, 10, 852. [CrossRef]

13. Dubey, S.P.; Lahtinen, M.; Sillanpää, M. Tansy fruit mediated greener synthesis of silver and gold nanoparticles. Process Biochem. 2010, 45, 1065-1071. [CrossRef]

14. Abboud, Y.; Saffaj, T.; Chagraoui, A.; El Bouari, A.; Brouzi, K.; Tanane, O.; Ihssane, B. Biosynthesis, characterization and antimicrobial activity of copper oxide nanoparticles (CONPs) produced using brown alga extract (Bifurcaria bifurcata). Appl. Nanosci. 2013, 4, 571-576. [CrossRef]

15. Yantcheva, N.S.; Karashanova, D.B.; Georgieva, B.C.; Vasileva, I.N.; Stoyanova, A.S.; Denev, P.N.; Dinkova, R.H.; Ognyanov, M.H.; Slavov, A.M. Characterization and application of spent brewer's yeast for silver nanoparticles synthesis. Bulg. Chem. Commun. 2019, 51, 173-177.

16. Yi, Z.; Ye, J.; Kikugawa, N.; Kako, T.; Ouyang, S.; Stuart-Williams, H.; Yang, H.; Cao, J.; Luo, W.; Li, Z.; et al. An orthophosphate semiconductor with photooxidation properties under visible-light irradiation. Nat. Mater. 2010, 9, 559-564. [CrossRef]

17. Cui, X.; Tian, L.; Xian, X.; Tang, H.; Yang, X. Solar photocatalytic water oxidation over $\mathrm{Ag}_{3} \mathrm{PO}_{4} / \mathrm{g}-\mathrm{C}_{3} \mathrm{~N}_{4}$ composite materials mediated by metallic Ag and graphene. Appl. Surf. Sci. 2018, 430, 108-115. [CrossRef] 
18. Gupta, A.; Mumtaz, S.; Li, C.H.; Hussain, I.; Rotello, V.M. Combatting antibiotic-resistant bacteria using nanomaterials. Chem. Soc. Rev. 2019, 48, 415-427. [CrossRef] [PubMed]

19. Magiorakos, A.-P.; Srinivasan, A.; Carey, R.B.; Carmeli, Y.; Falagas, M.E.; Giske, C.G.; Harbarth, S.; Hindler, J.F.; Kahlmeter, G.; Olsson-Liljequist, B.; et al. Multidrug-resistant, extensively drug-resistant and pandrug-resistant bacteria: An international expert proposal for interim standard definitions for acquired resistance. Clin. Microbiol. Infection 2012, 18, 268-281. [CrossRef] [PubMed]

20. ISO 1871:2009. Food and feed products-General guidelines for the determination of nitrogen by the Kjeldahl method. Available online: https: / / www.iso.org/standard/41320.html (accessed on 2 October 2021).

21. Grubesic, R.J.; Vukovic, J.; Kremer, D.; Vladimir-Knezevic, S. Spectrophotometric method for polyphenols analysis: Prevalidation and application on Plantago L. species. J. Pharm. Biomed. Anal. 2005, 39, 837-842. [CrossRef] [PubMed]

22. Hewitt, B.R. Spectrophotometric Determination of Total Carbohydrate. Nature 1958, 182, 246-247. [CrossRef]

23. Petkova, N.; Vrancheva, R.; Denev, P.; Ivanov, I.; Pavlov, A. HPLC-RID method for determination of inulin and fructooligosaccharides. In Proceedings of the Conference XI National Conference Natural Sciences 2013, "Bishop Konstantin Preslavski", Varna, Bulgaria, September 2013; pp. 23-28.

24. Cendejas-Bueno, E.; Rodriguez-Tudela, J.L.; Cuenca-Estrella, M.; Gomez-Lopez, A. Development and validation of a fast $\mathrm{HPLC}$ / photodiode array detection method for the measurement of voriconazole in human serum samples. A reference laboratory experience. Enferm. Infecc. Microbiol. Clin. 2013, 31, 23-28. [CrossRef]

25. Bisutti, I.; Hilke, I.; Raessler, M. Determination of total organic carbon—an overview of current methods. TrAC, Trends Anal. Chem. 2004, 23, 716-726. [CrossRef]

26. Kover, L.; Varga, D.; Cserny, I.; Toth, J.; Tokesi, K. Some applications of high-energy, high-resolution Auger-electron spectroscopy using Bremsstrahlung radiation. Surf. Interface Anal. 1992, 19, 9-15. [CrossRef]

27. Georget, D.M.R.; Belton, P.S. Effects of Temperature and Water Content on the Secondary Structure of Wheat Gluten Studied by FTIR Spectroscopy. Biomacromolecules 2006, 7, 469-475. [CrossRef]

28. Farhat, I.A.; Orset, S.; Moreau, P.; Blanshard, J.M.V. FTIR Study of Hydration Phenomena in Protein-Sugar Systems. J. Colloid Interface Sci. 1998, 207, 200-208. [CrossRef]

29. Zhbankov, R.G.; Firsov, S.P.; Buslov, D.K.; Nikonenko, N.A.; Marchewka, M.K.; Ratajczak, H. Structural physico-chemistry of cellulose macromolecules. Vibrational spectra and structure of cellulose. J. Mol. Struct. 2002, 614, 117-125. [CrossRef]

30. Duarte, I.F.; Barros, A.; Almeida, C.; Spraul, M.; Gil, A.M. Multivariate Analysis of NMR and FTIR Data as a Potential Tool for the Quality Control of Beer. J. Agric. Food Chem. 2004, 52, 1031-1038. [CrossRef]

31. Edelmann, A.; Lendl, B. Toward the Optical Tongue: Flow-Through Sensing of Tannin-Protein Interactions Based on FTIR Spectroscopy. J. Am. Chem. Soc. 2002, 124, 14741-14747. [CrossRef]

32. Talari, A.C.S.; Martinez, M.A.G.; Movasaghi, Z.; Rehman, S.; Rehman, I.U. Advances in Fourier transform infrared (FTIR) spectroscopy of biological tissues. Appl. Spectrosc. Rev. 2016, 52, 456-506. [CrossRef]

33. Zhou, C.; Jiang, W.; Via, B.K.; Fasina, O.; Han, G. Prediction of mixed hardwood lignin and carbohydrate content using ATR-FTIR and FT-NIR. Carbohydr. Polym. 2015, 121, 336-341. [CrossRef] [PubMed]

34. Hubbard, C.R. RIR-measurement and use in quantitative XRD. Powder Diff. 1988, 3, 74-77. [CrossRef]

35. Ma, J.; Niu, X.; Wang, J.; Wu, J. Facile synthesis of $\mathrm{Ag}_{3} \mathrm{PO}_{4}$ with the assistance of $\mathrm{N}, \mathrm{N}$-dimethylformamid and urea for high performance photocatalysis. Cat. Commun. 2016, 77, 55-59. [CrossRef]

36. Padmanabhan, S.K.; Pal, S.; Licciulli, A. Diatomite/silver phosphate composite for efficient degradation of organic dyes under solar radiation. Bull. Mater. Sci. 2020, 43, s12034-020. [CrossRef]

37. Saud, P.S.; Pant, B.; Twari, A.P.; Ghouri, Z.K.; Park, M.; Kim, H.Y. Effective photocatalytic efficacy of hydrothermally synthesized silver phosphate decorated titanium dioxide nanocomposite fibers. J. Colloid Interface Sci. 2016, 465, 225-232. [CrossRef]

38. Background analysis of XPS/AES QUASES Simple Backgrounds; 2.2; Tougaard Inc.: Odense, Denmark, $1999-2001$.

39. Mohai, M. XPS MultiQuant: Multimodel XPS quantification software. Surf. Interface Anal. 2004, 36, 828-832. [CrossRef]

40. Multimodel of X-ray photoelectron spectroscopy quantification program for 32-bit Windows. In XPSMuliQuant; ver. 7; Mohai, M.: Budapest, Hungary, 1999-2001.

41. Scofield, J.H. Hartree-Slater subshell photoionization cross-sections at 1254 and 1487 eV. J. Electron. Spectrosc. Relat. Phenom. 1976, 8, 129-137. [CrossRef]

42. NIST X-ray Photoelectron Spectroscopy Database, NIST Standard Reference Database Number 20, National Institute of Standards and Technology, Gaithersburg MD, 20899. 2000. (accessed on 1 May 2021). [CrossRef]

43. XPS Peak Fitting Program for WIN95/98 XPSPEAK; 4.1; Department of Chemistry, The Chinese University of Hong Kong: Shatin, Hong Kong, 2000.

44. Sulaeman, U.; Hermawan, D.; Andreas, R.; Abdullah, A.Z.; Yin, S. Native defects in silver orthophosphate and their effects on photocatalytic activity under visible light irradiation. Appl. Surf. Sci. 2018, 428, 1029-1035. [CrossRef]

45. Sulaeman, U.; Suhendar, S.; Diastuti, H.; Riapanitra, A.; Yin, S. Design of $\mathrm{Ag}_{3} \mathrm{PO}_{4}$ for highly enhanced photocatalyst using hydroxyapatite as a source of phosphate ion. Solid State Sci. 2018, 86, 1-5. [CrossRef]

46. Kaushik, V.K. XPS core level spectra and Auger parameters for some silver compounds. J. Electron. Spectrosc. Relat. Phenom. 1991, 56, 273-277. [CrossRef] 
47. Kibis, L.S.; Stadnichenko, A.I.; Pajetnov, E.M.; Koscheev, S.V.; Zaykovskii, V.I.; Boronin, A.I. The investigation of oxidized silver nanoparticles prepared by thermal evaporation and radio-frequency sputtering of metallic silver under oxygen. Appl. Surf. Sci. 2010, 257, 404-413. [CrossRef]

48. Rocha, T.C.; Oestereich, A.; Demidov, D.V.; Havecker, M.; Zafeiratos, S.; Weinberg, G.; Bukhtiyarov, V.I.; Knop-Gericke, A.; Schlogl, R. The silver-oxygen system in catalysis: New insights by near ambient pressure X-ray photoelectron spectroscopy. Phys. Chem. Chem. Phys. 2012, 14, 4554-4564. [CrossRef]

49. Mikhlin, Y.L.; Vishnyakova, E.A.; Romanchenko, A.S.; Saikova, S.V.; Likhatski, M.N.; Larichev, Y.V.; Tuzikov, F.V.; Zaikovskii, V.I.; Zharkov, S.M. Oxidation of Ag nanoparticles in aqueous media: Effect of particle size and capping. Appl. Surf. Sci. 2014, 297, 75-83. [CrossRef]

50. Lesiak, B.; Kövér, L.; Tóth, J.; Zemek, J.; Jiricek, P.; Kromka, A.; Rangam, N. C sp2/sp3 hybridisations in carbon nanomaterialsXPS and (X)AES study. Appl. Surf. Sci. 2018, 452, 223-231. [CrossRef]

51. Vorobyev, S.; Vishnyakova, E.; Likhatski, M.; Romanchenko, A.; Nemtsev, I.; Mikhlin, Y. Reactivity and Chemical Sintering of Carey Lea Silver Nanoparticles. Nanomaterials 2019, 9, 1525. [CrossRef] [PubMed]

52. QUASES-Tougaard Background Analysis of XPS/AES Part1-QUASES-Analyze; 5.0; Tougaard Inc.: Odense, Denmark, $1994-2003$.

53. Tanuma, S.; Powell, C.J.; Penn, D.R. Calculations of electron inelastic mean free paths. V. Data for 14 organic compounds over the 50-2000 eV range. Surf. Interface Anal. 1993, 21, 165-176. [CrossRef]

54. Kubasheva, Z.; Sprynskyy, M.; Railean-Plugaru, V.; Pomastowski, P.; Ospanova, A.; Buszewski, B. Synthesis and Antibacterial Activity of (AgCl, Ag)NPs / Diatomite Hybrid Composite. Materials 2020, 13, 3409. [CrossRef] [PubMed]

55. Iravani, S. Green synthesis of metal nanoparticles using plants. Green Chem. 2011, 13, 2638. [CrossRef]

56. El-Seedi, H.R.; El-Shabasy, R.M.; Khalifa, S.A.M.; Saeed, A.; Shah, A.; Shah, R.; Iftikhar, F.J.; Abdel-Daim, M.M.; Omri, A.; Hajrahand, N.H.; et al. Metal nanoparticles fabricated by green chemistry using natural extracts: Biosynthesis, mechanisms, and applications. RSC Adv. 2019, 9, 24539-24559. [CrossRef]

57. Meshram, S.M.; Bonde, S.R.; Gupta, I.R.; Gade, A.K.; Rai, M.K. Green synthesis of silver nanoparticles using white sugar. IET Nanobiotechnol. 2013, 7, 28-32. [CrossRef] [PubMed]

58. Dwivedi, A.D.; Gopal, K. Biosynthesis of silver and gold nanoparticles using Chenopodium album leaf extract. Colloids Surf. A 2010, 369, 27-33. [CrossRef]

59. Lin, Z.; Wu, J.; Xue, R.; Yang, Y. Spectroscopic characterization of $\mathrm{Au}^{3+}$ biosorption by waste biomass of Saccharomyces cerevisiae. Spectrochim. Acta A Mol. Biomol. Spectrosc. 2005, 61, 761-765. [CrossRef]

60. Deshmukh, S.P.; Patil, S.M.; Mullani, S.B.; Delekar, S.D. Silver nanoparticles as an effective disinfectant: A review. Mater. Sci. Eng. C Mater. Biol. Appl. 2019, 97, 954-965. [CrossRef]

61. Mikhailova, E.O. Silver Nanoparticles: Mechanism of Action and Probable Bio-Application. J. Funct. Biomater. 2020, 11, 84. [CrossRef]

62. CRC Handbook of Chemistry and Physics, 99th ed.; Rumble, J., Ed.; CRC Press: Boca Raton, FL, USA, 2018. 